\title{
Globalization, industrialization and labour markets in China
}

\author{
Miao Zhang \\ University of Malaya, Malaysia \\ Rajah Rasiah \\ University of Malaya, Malaysia \\ Sarosh Kuruvilla \\ Cornell University
}

China's experience with globalization is still contested. This paper seeks to examine the impact of global integration and industrialization on labour markets in China. The evidence shows that rising trade and flows of foreign direct investment has not only quickened industrialization and structural change but it has also stimulated a rapid rise in overall and manufacturing real wages. The government's framework of absorbing marketization while maintaining planning control through decentralization has been critical in the development of technological capabilities in manufacturing. Although the nature of economic development after reforms has also widened regional inequalities with the Eastern coastal provinces enjoying higher growth and structural change than the Western and other inland provinces, rising wages suggest that the material conditions of the majority of workers in China have improved.

Keywords: globalization; industrialization; labour markets; China

JEL Classifications: J21; L60; 014; 018

\section{Introduction}

When China announced its reform plans in 1978, few could have anticipated the miraculous growth that it will record, especially since 1992. Under the leadership of Mao, China had built the elements of nationalism for the central government to direct economic development, which helped a nationally united command economy to stimulate economic development through the unleashing of market forces, private dwellers and rapid integration into the global economy. Trade and investment flows brought China closer to the global economy. From specialization in light manufactured exports, China has undergone considerable structural change to participate in heavy and knowledge-intensive manufactured goods (Rasiah, Miao, and Xin, 2013). However, some economists have questioned 
China's rapid growth by either claiming that official statistics are not reliable or that it has largely been propelled by agriculture, land use and labour-intensive industries (Young 2003). 'Even more so China's labour markets remain under-examined from the standpoint of whether rapid growth has been reflected in improvements to wages and working conditions. The latter is important to determine if China is following the high road to industrialization.

The historical precursor of industrialization in China can be traced to the Song Dynasty (960_1279) when steel was invented and produced and used extensively by the public. A series of pre-modern technological innovation and evolution of intellectual thought during the Song Dynasty

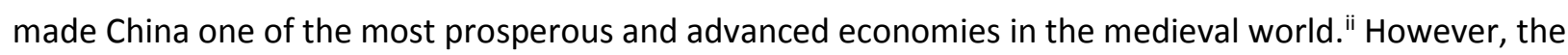
weak succeeding regimes that followed did not carry this forward. In fact, large parts of China were colonized by the Western countries and Japan. After the establishment of People's Republic of China (PRC), a real sense of industrialization did not happen until 1958 when the controversial campaign The Great Leap Forward was advanced by Mao Zedong. His aim to transform the newly born PRC from an agrarian economy to a modern communist society through state-led industrialization eventually failed. GDP per capita fell from 200 yuan in 1958 to 173 yuan in 1960. Thanks to reforms, industrialization resumed rapidly under the Deng Xiaoping Administration.

An assessment of globalization, industrialization and labour markets in China is important not only because of its rising importance as a major economic power but also because of its transformation from an agricultural economy to an industrial economy. The analysis will not only offer an opportunity to examine the contrasting passion scholars have on China. On the one hand, some accept the reality over the surge in industrialization and Chinese exports as an example of a successful development model in which the state has allowed market forces to operate within those social boundaries (e.g. Rasiah, Miao, and Xin, 2013). On the other hand, critics claim that Chinese data is fudged, and that the rapid growth is unsustainable owing to growing fuel deficits and environment disasters.

Hence, this paper seeks to examine the impact of globalization and industrialization on China's labour market since reforms began. Specifically, the paper seeks to capture the impact of industrial structural change on the domestic labour market. Unlike neoliberal expositions of globalization, we will provide evidence to show that the complex nature of government policy in China was structured to allow both the provincialization, as well as, the localization of planning (Zhang and Rasiah 2014). Also, industrialization was promoted by the government taking account of the specific characteristics of the industries, the targets set for them, and provincial and municipal endowments. The rest of the paper is organized as follows. Sections 2 and 3 examine globalization and industrialization in China with a focus 
on structural change. Section 4 analyses the demand supply model of labour market and discusses the impact of globalization and industrialization on it. Section 5 concludes with policy implications.

\section{Trade and investment flows}

While the globalization concept has a wide meaning that includes qualitative exchange of information and the forces shaping the process, for measurement purposes we confine the assessment to quantitative flows of trade and investment. Hence, we discuss trade and into the global capitalist economy expanded since the launching of the Opening Door Policy in 1978, global flows of trade and investment into China was marked by two major waves, the first taking place in the mid-1980s followed by the early 1990s and subsequently since 2001 .

\subsection{Trade}

Between 1978 and 2000, the Chinese economy grew gently but began to switch gears to rapidly expand since 2001 following its membership of the World Trade Organization. Except for a decline in 2009 due to the global financial crisis, exports, imports and total trade of goods grew from US\$266.1 billion, US\$243.5 billion and US\$509.6 billion, respectively in 2001 to US\$1898.4 billion, US\$1743.5 billion and US\$3641.9 billion, respectively in 2011 (Figure 1), which expanded the share of trade in GDP from 5\% in 1979 to its peak of 70\% in 2007 before falling to 59\% in 2011 (Figure 2). 


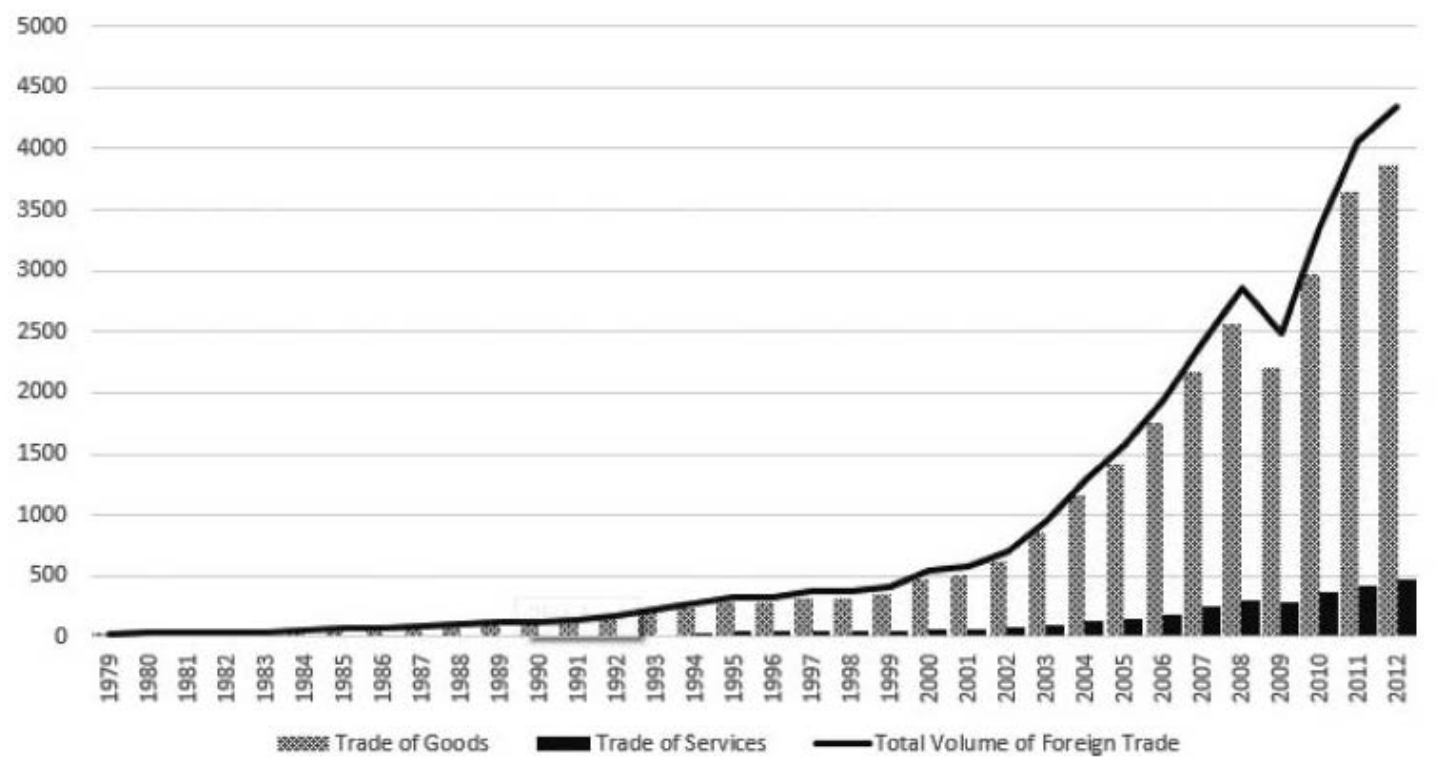

Figure 1. Import and expott of goods and services, China, 1979-2012 (US\$ billion). Source: Ministry of Commerce of China, various years.

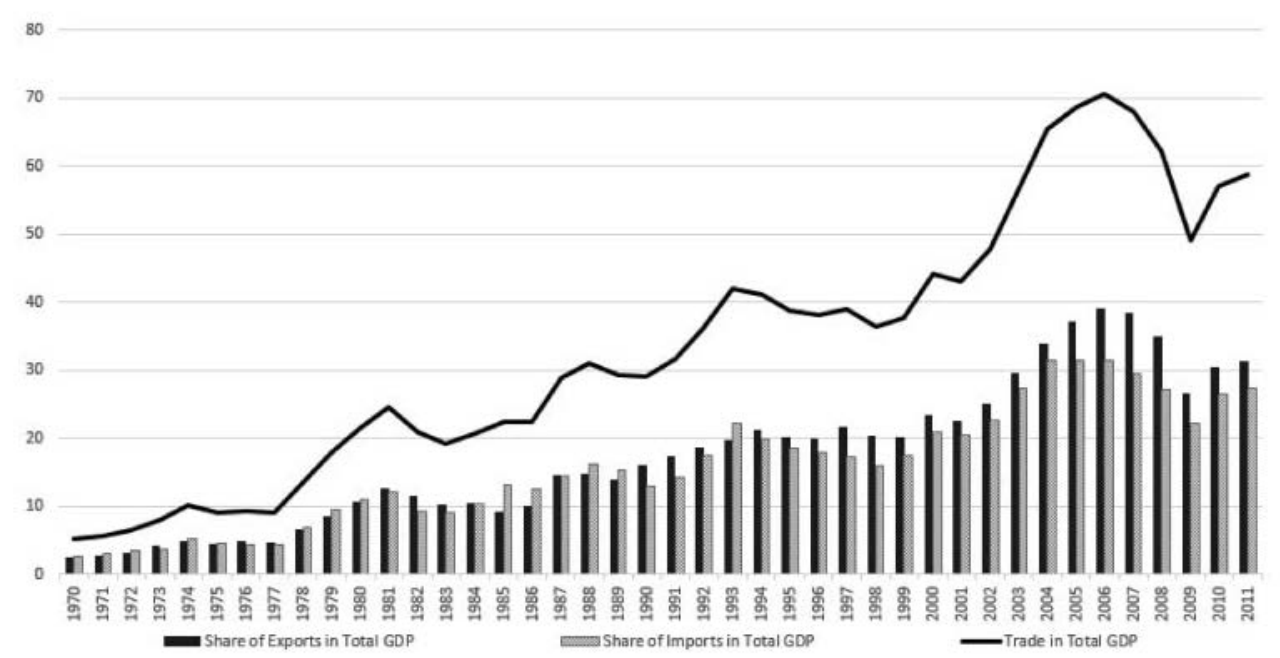

Figure 2. Share of import and export in total GDP (Goods and Services), China, 1970-2011.

Source: World Bank Institute (2012).

China's share in world exports rose from 1.2\% in 1983 to 11.4\% in 2012 (Table 1). Figure 3 shows that growth in exports from China exceeded growth in world exports in the period 2001_2007. Although always less than exports the share of import in world merchandise also recorded significant expansion from $1.1 \%$ in 1983 to $10 \%$ in 2012. China ranked first in world exports of merchandise and second in trade (exports plus imports) totaling US\$3867 billion in 2012 (Figure 4). The trade surplus of China reached US\$230 billion in 2012 amounting to $2.8 \%$ of GDP. 
Trade has played an important role in stimulating economic growth in China, but the biggest beneficiaries have been the sea-fronted Eastern provinces. Proximity to the sea has resulted in the proliferation of special economic zones (SEZs) in the coastal cities, such as Guangdong, which accounted for approximately one-third of China's trade, though it fell from 36\% in 2000 to 26\% in 2010 (Figure 5). Efforts by the central government to reduce provincial inequality saw the rise of inland provinces so that Jiangsu and Beijing recorded sizeable amount of trade in 2010. However, regional inequality has persisted as the outlying provinces of Tibet, Xinjiang and Guizhou have remained poor.

Table 1. Share of exports and imports in World Merchandise Trade, China, 1948-2012 (\%).

\begin{tabular}{lcccccccc}
\hline & 1948 & 1953 & 1963 & 1973 & 1983 & 1993 & 2003 & 2012 \\
\hline Export & 0.9 & 1.2 & 1.3 & 1.0 & 1.2 & 2.5 & 5.9 & 11.4 \\
Import & 0.6 & 1.6 & 0.9 & 0.9 & 1.1 & 2.7 & 5.4 & 10.0
\end{tabular}

Source: World Trade Organization (2012).

\subsection{Foreign direct investment}

Aided by market reforms and accession to the WTO, China has become a major recipient of FDI in the world. China has also begun investing abroad, especially in the South countries. We examine China's integration in the global economy through FDI flows in this section. 


\subsubsection{Inward foreign direct investment}

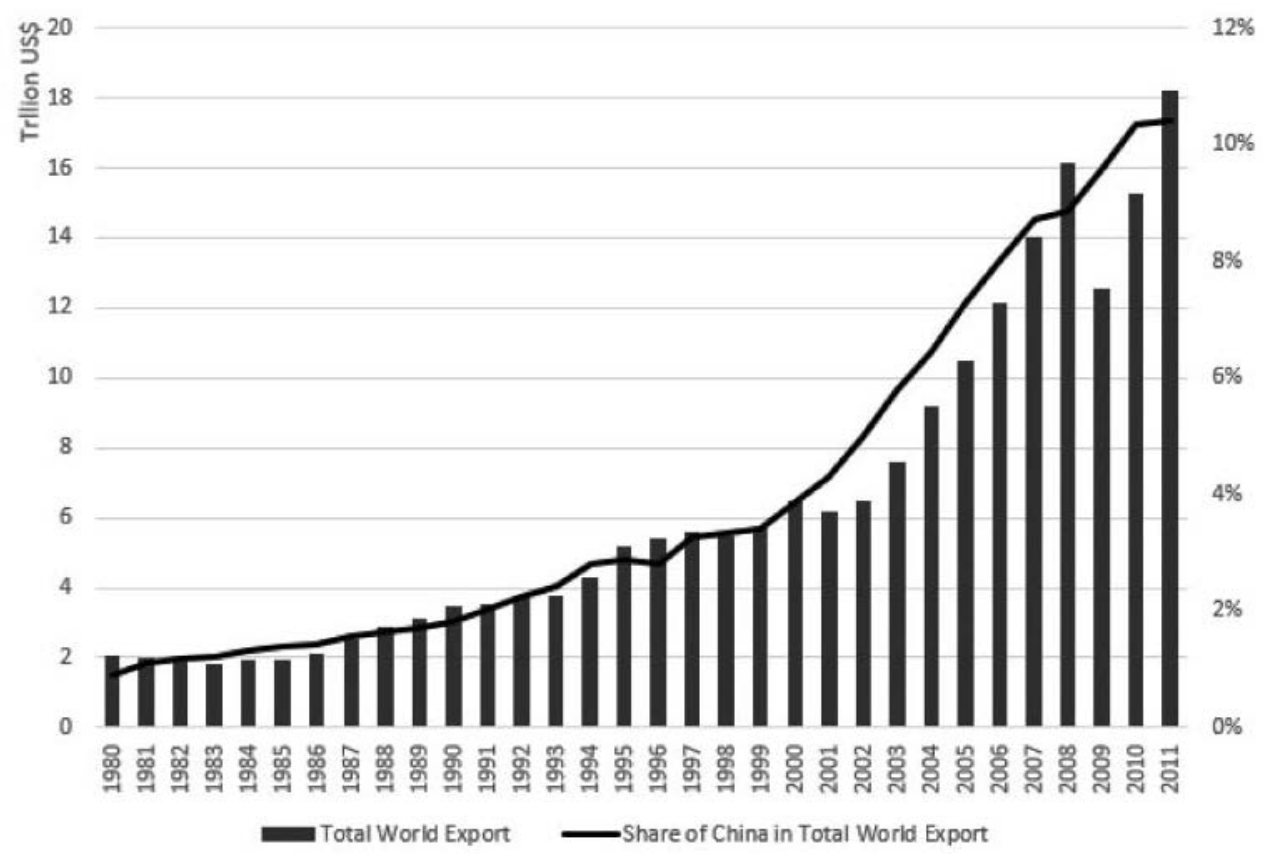

Figure 3. China's share in world exports, 1980-2011.

Source: China Foreign Economic Statistical Yearbook (2012).

China has also strongly integrated in the global economy through inward foreign direct investment (FDI), which rose from US\$20.7 billion in 2000 to US\$193.3 billion in 2005 and US\$578.8 billion in 2010 (UNCTAD 2011, 193). Inward FDI as a share of GDP rose from 1\% in 1991 to over 6\% in 1993 before falling as a consequence of the Asian Financial Crisis. The jump in FDI in 1993 was a direct result of Deng Xiaoping's South Tour in the summer of 1992, which was accompanied by the opening of four SEZs in the country. The campaign to realize China's industrialization through joint ventures was launched to 'attract foreign technology in the industrial sector by leveraging on the domestic market.' FDI has not only helped modernize China's backward industrial sector by introducing cutting-edge technology, it has also quickened the shift in manufacturing operations from labour-intensive to technology-intensive operations. Except for the financial- crisis affected year of 2009, inward FDI registered over 3\% of GDP over the period 2005_2013 (Figure 6). 


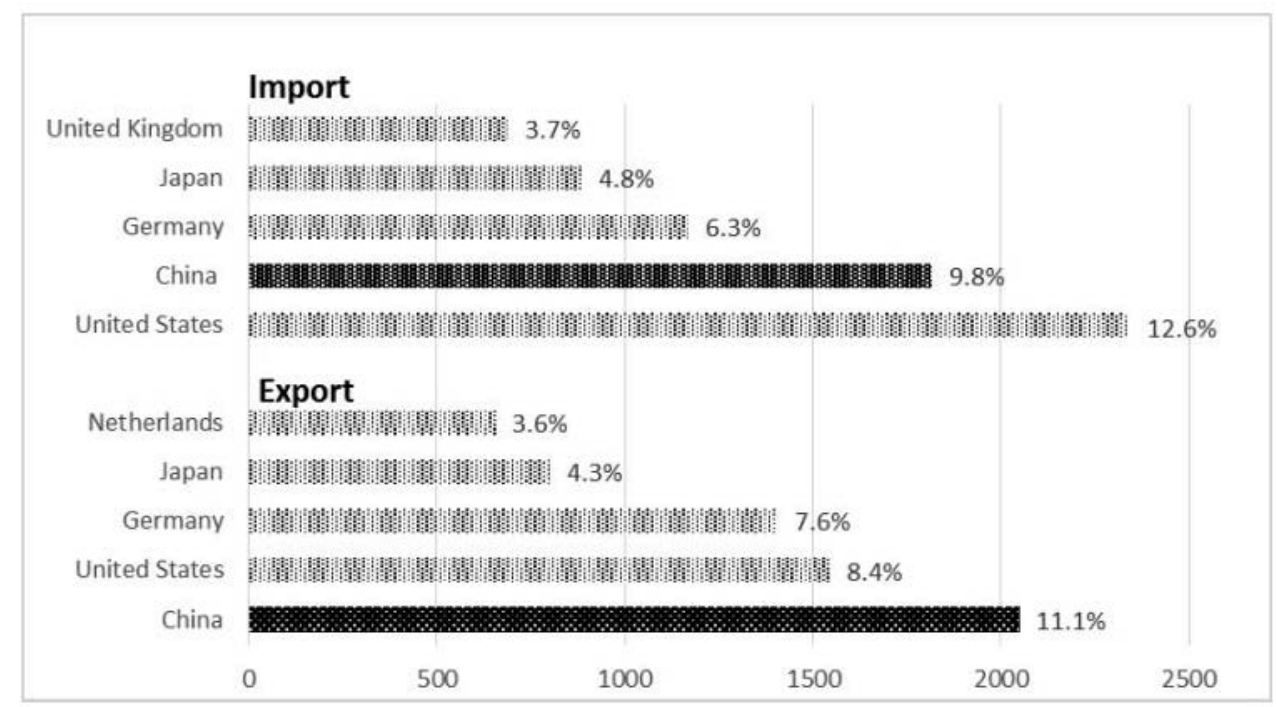

Figure 4. Top five exporters and importers by trade value in the world, 2012 (US\$ billion). Source: World Trade Organization (2012).

The sectoral distribution shows that export-oriented labour-intensive manufacturing sector is the main destination of FDI, though its share fell from 71\% in 2000 to $47 \%$ in 2010 (Table 2). However, despite falling shares, actual FDI into manufacturing experienced grew slightly from US\$44 billion in 2000 to US\$49 billion in 2010. However, except for equipment manufacturing _ which enjoyed FDI shares rising from $4.3 \%$ in 2000 to $6.1 \%$ in 2010 , the remaining sectors experienced falling FDI shares. Nevertheless, the growing real estate sector led by a price boom in 2003, began to attract strong inflows of FDI so that its share in overall FDI rose from $8.4 \%$ in 2000 to $22.7 \%$.

Any assessment of the impact of globalization on China will not be complete without an account of FDI and its impact on International trade. Enjoying access to duty free imports when exporting, foreign firms share in exports rose from $0.2 \%$ in 1981 to its peak of $58.3 \%$ in 2005 before falling to $49.9 \%$ in 2012 (Table 3). Foreign firms' share in imports rose from 0.5\% in 1981 to its peak of 59.7\% in 2006 before falling to $47.9 \%$ in 2012. The export:import ratio improved in trend terms from 19.2 in 1981 to its peak of 124.3 in 2007. It has exceeded 100 over the period 1997_2012 demonstrating a positive trade balance over that period. 

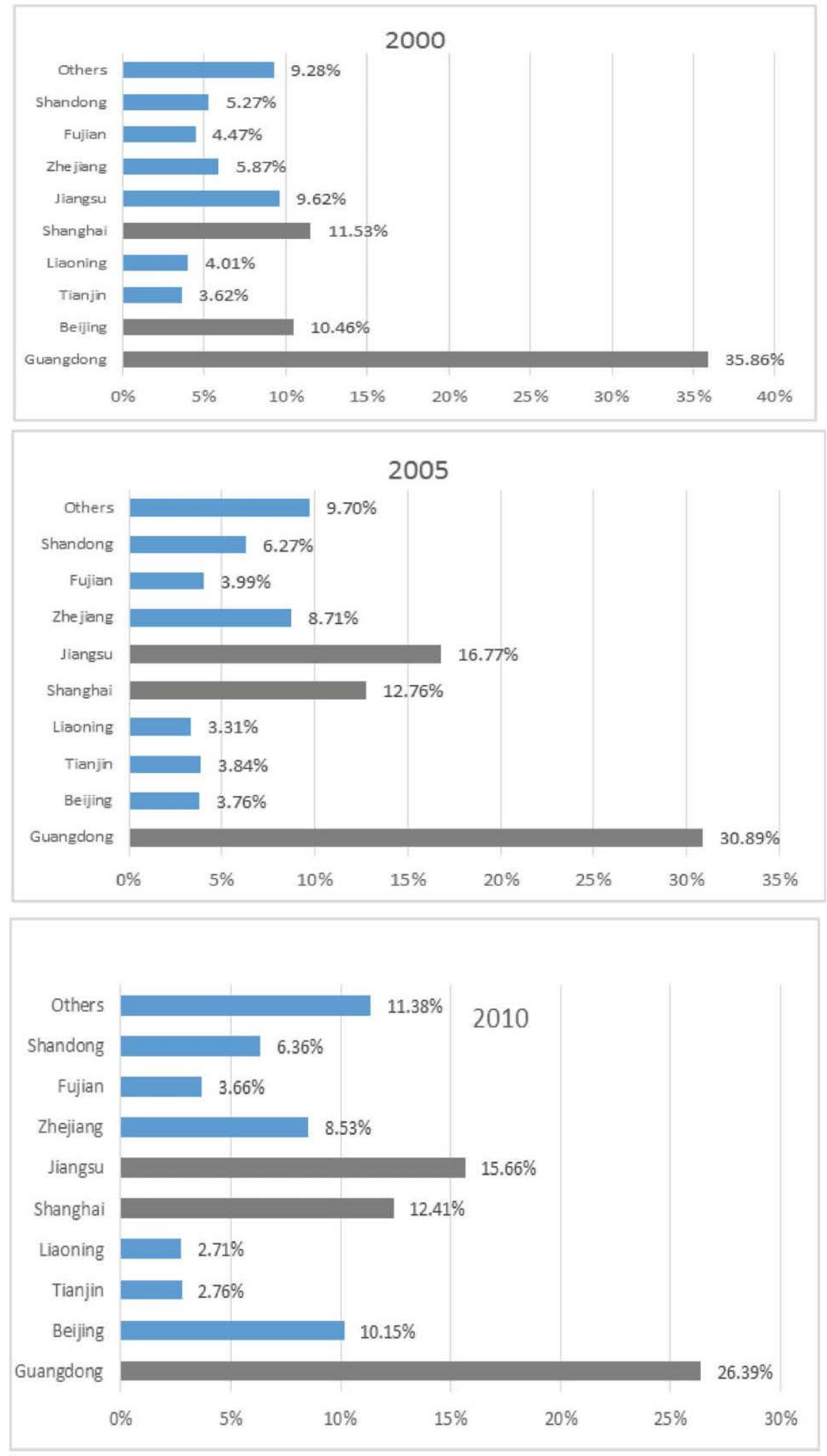

Figure 5. Provincial trade, China, 2000-2010 (\%). Source: China Statistical Bureau (various years). 


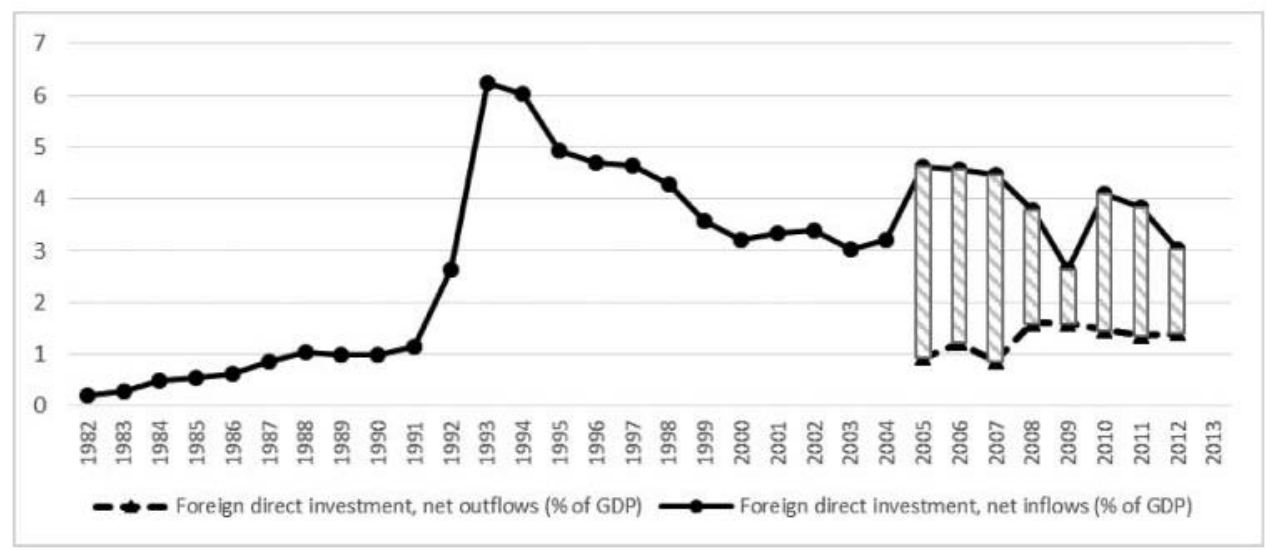

Figure 6. Share of foreign direct investment in GDP, Net Inflows and Outflows, China, $1982-2013$.

Source: World Development Indicators (2012).

\subsubsection{Outward FDI}

Chinese FDI outflows have also become important especially after new century. Between 2005 and 2010, Europe, the United States and Australia attracted US\$43.2 billion, US\$30.4 billion and US\$38.4 billion FDI, respectively from China (Figure 7). Regionally, China's outward FDI has also flowed considerably to South America (US\$72.3 billion), Sub-Saharan Africa (US\$56.4 billion), West Asia (US\$51.7 billion), the Arab countries (US\$43.7 billion) and East Asia (US\$42.6 billion).

Sectorally, energy and power, especially in Sub-Saharan Africa, West Asia and the Arab countries, have been the leading destination of China's outward FDI, which accounted for US\$61.8 billion in 2011. In addition, large engineering and construction contracts, such as railway, roads, bridges and stadiums have also been important. The finance and real estate sectors attracted US\$16.5 billion while agriculture received US\$6.4 billion in 2011. Hence, despite the well-known fact that China's outward foreign capital has mostly been confined to portfolio investments in American government bonds, its non-bonds investment flows show strong sectoral and geographic diversification as a consequence of its increasing integration into the world economy.

Motivated by the national strategy of 'go-aboard' with a set of supportive policy diplomatically and financially since 1998, outward FDI (the contract value from China) rose from US\$11.7 billion in 1998 to US\$142 billion in 2011 (Figure 8). The huge current and capital account surpluses with foreign reserves reaching US\$3.31 trillion in 2012 has made China a major capital exporter. Whereas 
traditionally, China invests extensively into energy and manufacturing in the developing economies, falling property prices following the global financial crisis has attracted massive Chinese investment into the developed economies of the US and Britain. Meanwhile, Chinese firms have also begun to acquire established foreign firms to quicken technological catch up. For example, Lenovo and Geely acquired International Business Machines (IBM) and Volvo in 2005 and 2010, respectively.

Table 2. FDI in manufacturing and real estate, China, 2000-2010.

\begin{tabular}{|c|c|c|c|c|c|c|c|c|}
\hline \multirow{2}{*}{$\begin{array}{l}\text { Year } \\
\text { Item }\end{array}$} & \multicolumn{2}{|c|}{2010} & \multicolumn{2}{|c|}{2008} & \multicolumn{2}{|c|}{2005} & \multicolumn{2}{|l|}{2000} \\
\hline & Value $^{a}$ & $\%$ & Value & $\%$ & Value & $\%$ & Value $^{b}$ & $\%$ \\
\hline Total & $10,573,524$ & & $9,239,544$ & & $6,032,469$ & & $6,237,952$ & \\
\hline Manufacturing & $4,959,058$ & 46.9 & $4,989,483$ & 54.0 & $4,245,291$ & 70.37 & $4,425,430$ & 70.94 \\
\hline Textile and clothing & 160,250 & 1.52 & 182,336 & 1.97 & 210,404 & 3.49 & 198,833 & 3.19 \\
\hline $\begin{array}{l}\text { Chemistry raw material } \\
\text { and chemical product }\end{array}$ & 343,655 & 3.25 & 412,326 & 4.46 & 280,884 & 4.66 & 259,444 & 4.16 \\
\hline Medicine & 102,847 & 0.97 & 65,753 & 0.71 & 55,549 & 0.92 & 91,153 & 1.46 \\
\hline $\begin{array}{l}\text { General purpose } \\
\text { equipment }\end{array}$ & 345,762 & 3.27 & 350,809 & 3.80 & 203,213 & 3.37 & 163,003 & 2.61 \\
\hline $\begin{array}{l}\text { Special purpose } \\
\text { equipment }\end{array}$ & 312,874 & 2.96 & 281,638 & 3.05 & 194,123 & 3.22 & 106,585 & 1.71 \\
\hline Computer and electronic & 843,210 & 7.97 & 845,143 & 9.15 & 771,117 & 12.78 & $1,135,615$ & 18.20 \\
\hline Real Estate & $2,398,556$ & 22.68 & $1,858,995$ & 20.12 & 541,807 & 8.98 & 523,213 & 8.39 \\
\hline
\end{tabular}

Note: ${ }^{\circ}$ Value in 2005,2008 and 2010 is actual use of FDI by US $\$ 10,000$;

balue in 2000 is contractual value by US $\$ 10,000$.

Source: China Trade and External Economic Statistical Yearbook (various years).

Table 3. Share of foreign-funded firms in imports and exports, China, 1981-2012.

\begin{tabular}{|c|c|c|c|c|c|c|c|}
\hline \multirow[b]{2}{*}{ Year } & \multicolumn{2}{|c|}{ Imports and exports } & \multicolumn{2}{|c|}{ Exports } & \multicolumn{2}{|c|}{ Imports } & \multirow[b]{2}{*}{ Export/import (\%) } \\
\hline & Value $^{\mathrm{a}}$ & $\%$ in total & Value & $\%$ in total & Value & $\%$ in total & \\
\hline 1981 & 1.43 & 0.33 & 0.33 & 0.15 & 1.1 & 0.5 & 19.20 \\
\hline 1986 & 30.12 & 4.08 & 5.82 & 1.88 & 24.3 & 5.66 & 38.69 \\
\hline 1991 & 289.55 & 21.33 & 120.47 & 16.75 & 169.08 & 26.5 & 65.82 \\
\hline 1996 & 1371.1 & 47.3 & 615.06 & 40.71 & 756.04 & 54.46 & 96.37 \\
\hline 2001 & 2590.98 & 50.82 & 1332.35 & 50.05 & 1258.63 & 51.66 & 105.86 \\
\hline 2006 & $10,364.51$ & 58.87 & 5638.35 & 58.18 & 4726.16 & 59.7 & 119.30 \\
\hline 2007 & $12,549.28$ & 57.73 & 6955.2 & 57.1 & 5594.08 & 58.53 & 124.33 \\
\hline 2008 & $14,105.76$ & 55.07 & 7906.2 & 55.34 & 6199.56 & 54.71 & 127.53 \\
\hline 2009 & $12,174.37$ & 55.16 & 6722.3 & 55.94 & 5452.07 & 54.22 & 123.30 \\
\hline 2010 & $16,003.07$ & 53.83 & 8623.06 & 54.65 & 7380.01 & 52.91 & 116.84 \\
\hline 2011 & $18,601.56$ & 51.07 & 9953.3 & 52.42 & 8648.26 & 49.6 & 115.09 \\
\hline 2012 & $18,939.97$ & 48.98 & $10,227.48$ & 49.92 & 8712.49 & 47.93 & 117.39 \\
\hline
\end{tabular}

Note: ${ }^{\mathrm{a}}$ In US $\$ 100$ million.

Source: Ministry of Commerce (various years). 


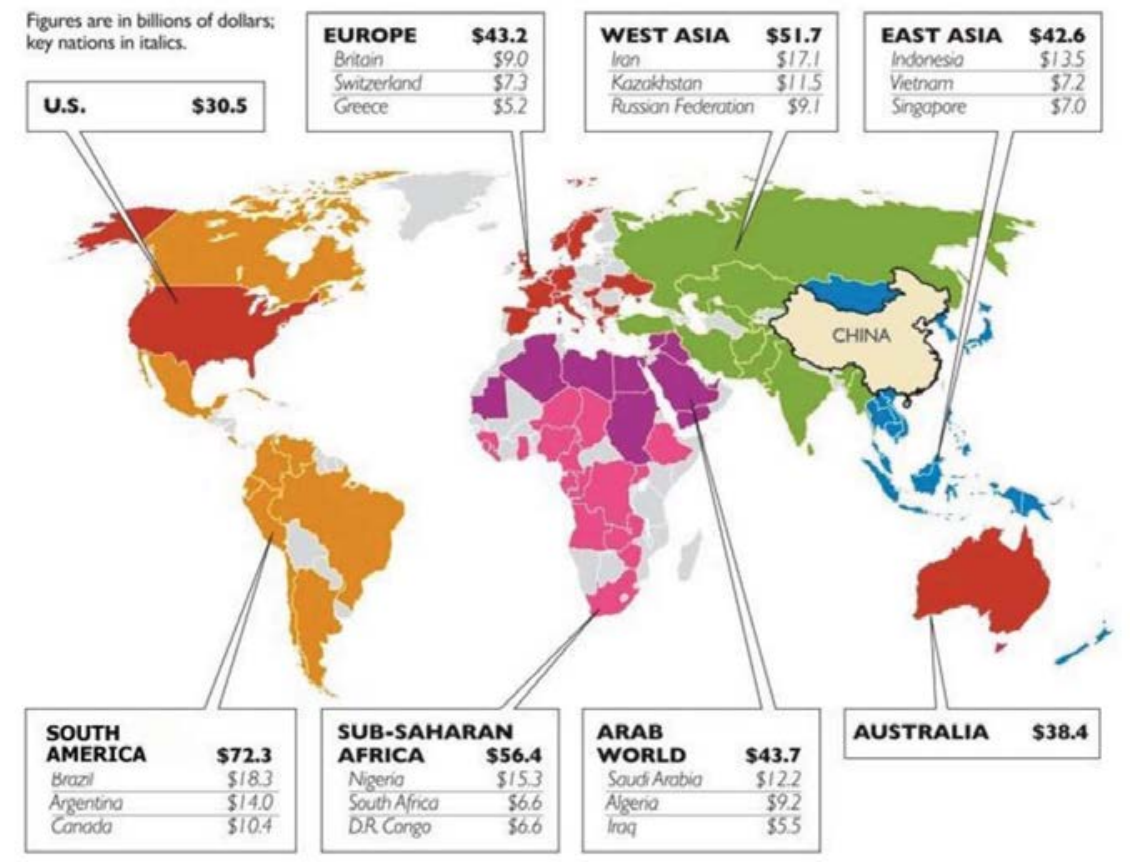

Figure 7. Outward FDI, China, 2011.

Source: China Global Investment Tracker (2011).

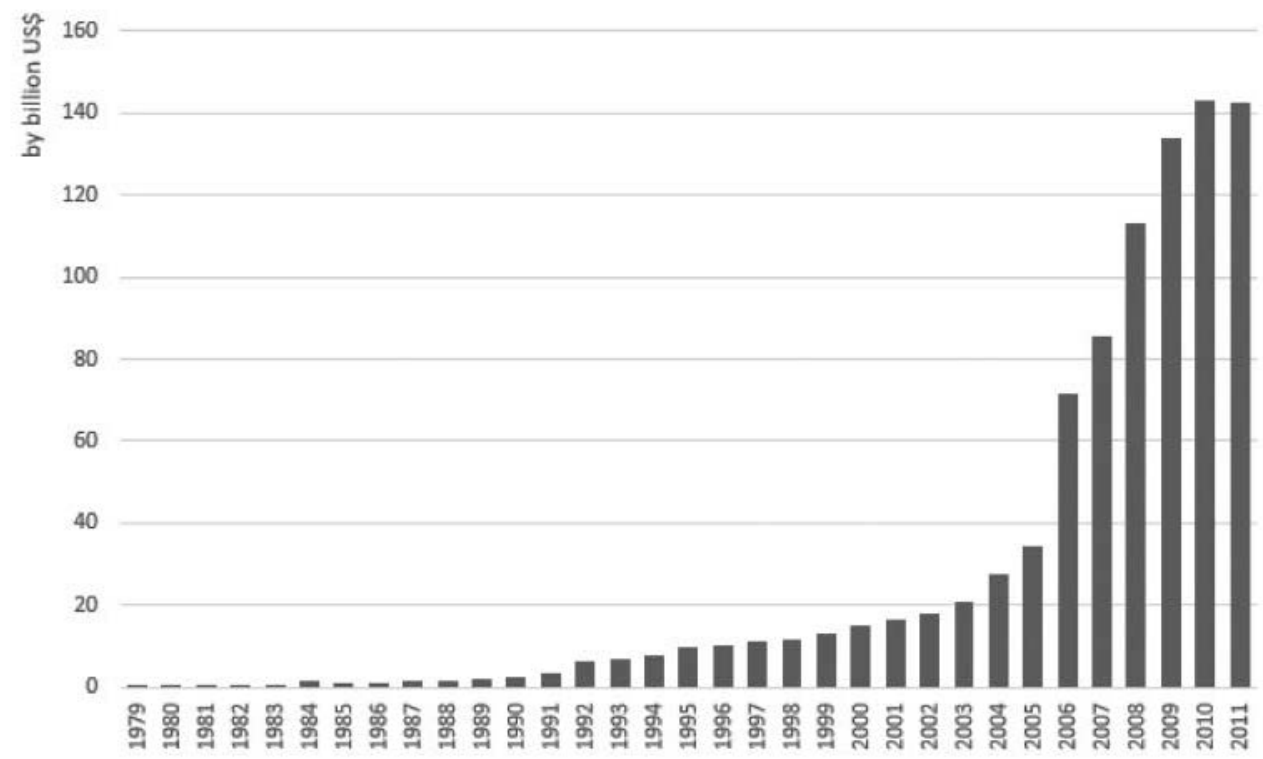

Figure 8. Outward FDI by contracted value, China, 1979-2011.

Source: China Statistical Bureau (2012a). 


\section{Industrialization}

While global integration has been important, government focus on stimulating technological capability building was no less important in the rapid growth of manufacturing in China. Clearly, the focus on capital accumulation was directed at technological capability building.

Government promotion of manufacturing took on three different instruments. The first was a central government initiative that started in 1978 when four SEZs were created to attract exportoriented industries, 14 cities were declared as coastal open cities in 1984 and regional development plans involving the three Delta schemes of Yangze River, Min Jiang and Pearl River Valleys. Where the industries promoted were identified as strategic, import controls (duties, quotas and licenses were used by the central government to promote high technology industries, such as automobiles and electronics). Government policies emphasized technology transfer to national firms when the domestic market was important. This was the basis on which Volkswagen was approved to produce and supply cars in the Chinese market. iii These controls were not used where production was largely for foreign markets. The Chinese government also offered special incentives by way of grants and tax breaks to promote high technology industries and technological upgrading.

At the same time, local governments were given the autonomy to implement central government initiatives (e.g. subsidized land lease rights and utilities, customs coordination), as well as, more importantly strategize to promote technological capability building in industries where the focus is on technological upgrading. Examples of successful local initiatives include efforts by the Shanghai government in the late 1980s to mandate that the Santana, a car produced by the Shanghai Volkswagen joint venture, be the only legitimate taxi to run in the city. Similarly, the Yongjia county and the Qiaotou

municipality in Zhejiang province played a critical role in establishing cluster links between the firms and the designing and R\&D centres with support from universities to stimulate technological upgrading in the button industry (Rasiah, Kong, and Vinanchiarachi 2011). Provincial governments also invested heavily into high-tech parks to stimulate technological upgrading in the high technology industries.

Led by government initiatives, FDI and international trade, the manufacturing sector in China has flourished since economic reforms began. As Zhang and Rasiah (2014) have shown market reforms helped raise efficiency and coordination, the state has remained in control of important decisions to stimulate technological upgrading and improvement of the material conditions of the people. China's share in world manufactured exports grew from $1.9 \%$ in 1990 to $4.7 \%$ in 2000 and to $16.8 \%$ in 2012. At the same time, manufacturing, which accounted for $94 \%$ of China's exports in 2012, 
saw a tremendous growth of its share in export in the world from $1.9 \%$ in 1990 to $4.7 \%$ in 2000 before it reached $16.8 \%$ in 2012.

The share of manufacturing in total imports expanded sharply to $58 \%$ in 1987 after bottoming to 26\% in 1985 (Figure 9). However, manufacturing's share in exports and imports grew strongly in the 1990 s to reach almost $80 \%$ each respectively in 1994 . Whereas export shares have continued to rise to reach $94 \%$, import shares fell to $56 \%$ in 2012 . A combination of rising fuel imports and stronger domestic manufacturing production capabilities accounted for a fall in the share of manufactured imports in total imports (Rasiah, Miao, and Xin, 2013).

Manufacturing is the key component of the industrial sector with construction and utilities being the other components (Kaldor 1967). Although industrialization reached its highest share in GDP during the Great Leap Forward campaign in 1958, modern manufacturing did not seriously take off until the economic reforms. Its contribution to GDP has hovered around 30\%_35\% in the period 1984_2010 (Figure 10). In addition, the contribution of industrial output in GDP has remained strong to reach $47 \%$ in 2011. Although the contribution of manufacturing value added in GDP fell in 2008_2010 owing to a crash in exports caused by contracting imports from the developed economies, it grew in real prices from US\$12 billion in 1965 to US\$1243 billion in 2010 (Figure 11). Indeed, except for the steep growth recorded in 1967 (because of its small starting base), manufacturing value added grew strongest and in a sustained way in China since 1993.

China has enjoyed significant manufacturing structural change as the capital goods industry of machinery and transport equipment recorded the highest share, which rose from $18 \%$ in 1992 to $24 \%$ in 2007 (Table 4). The contribution of textiles and clothing fell from $12.9 \%$ in 1992 to $10.0 \%$ in 2007 . While growth in demand _ both domestic and foreign has been important, the role of the central, provincial and municipal governments have also been critical in stimulating innovation and technological upgrading in manufacturing. ${ }^{\text {iv }}$

In short, it is clear that China has undergone significant globalization and structural change with manufacturing showing a shift towards the higher value added activities of machinery and transport equipment. It will be interesting to see if these developments have translated into a high road to industrialization in the next section. 


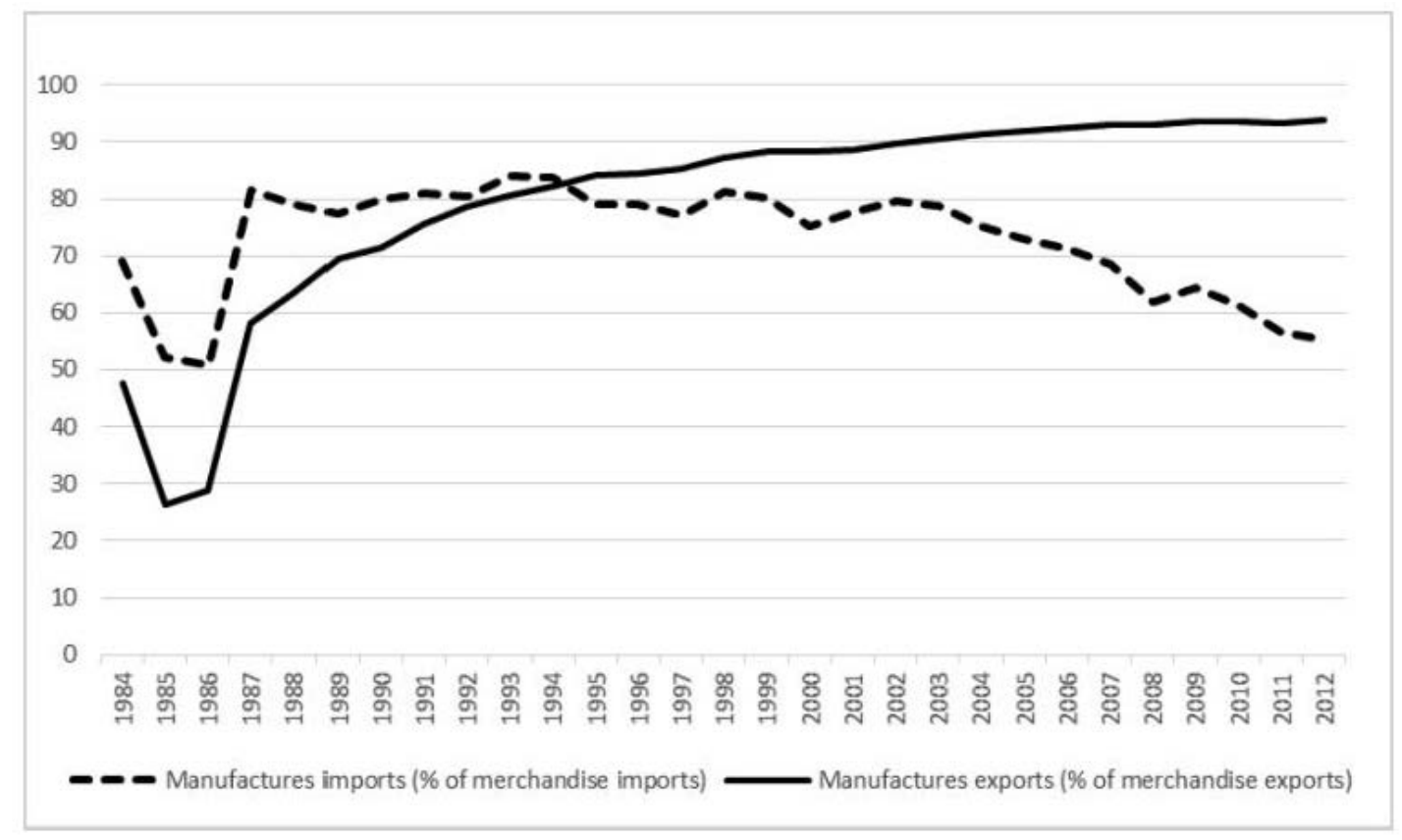

Figure 9. Share of manufacturing in imports and exports, China, 1984-2012.

Source: World Bank (2012).

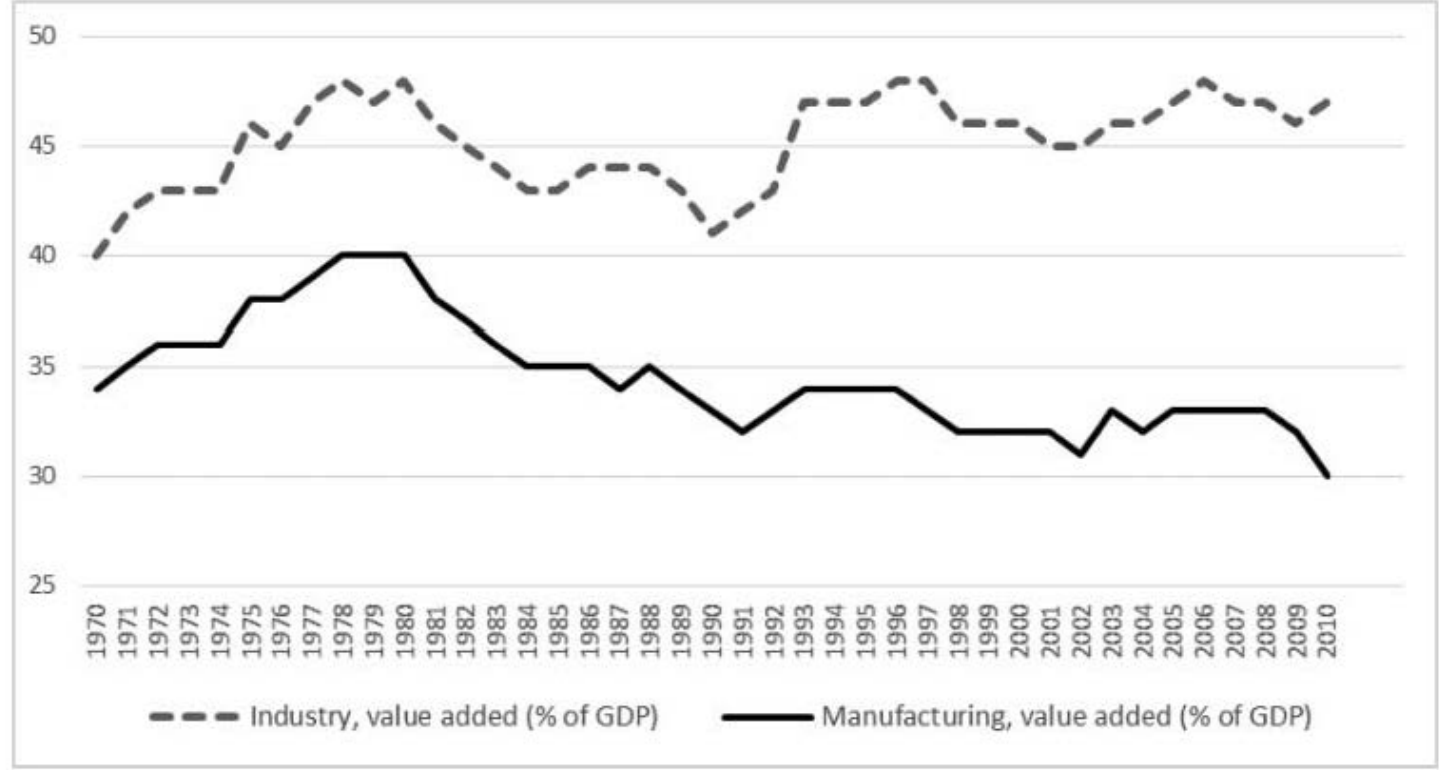

Figure 10. Share of industrial and manufacturing sectors in GDP, China, 1970-2010. Source: China Statistical Bureau (2010a). 


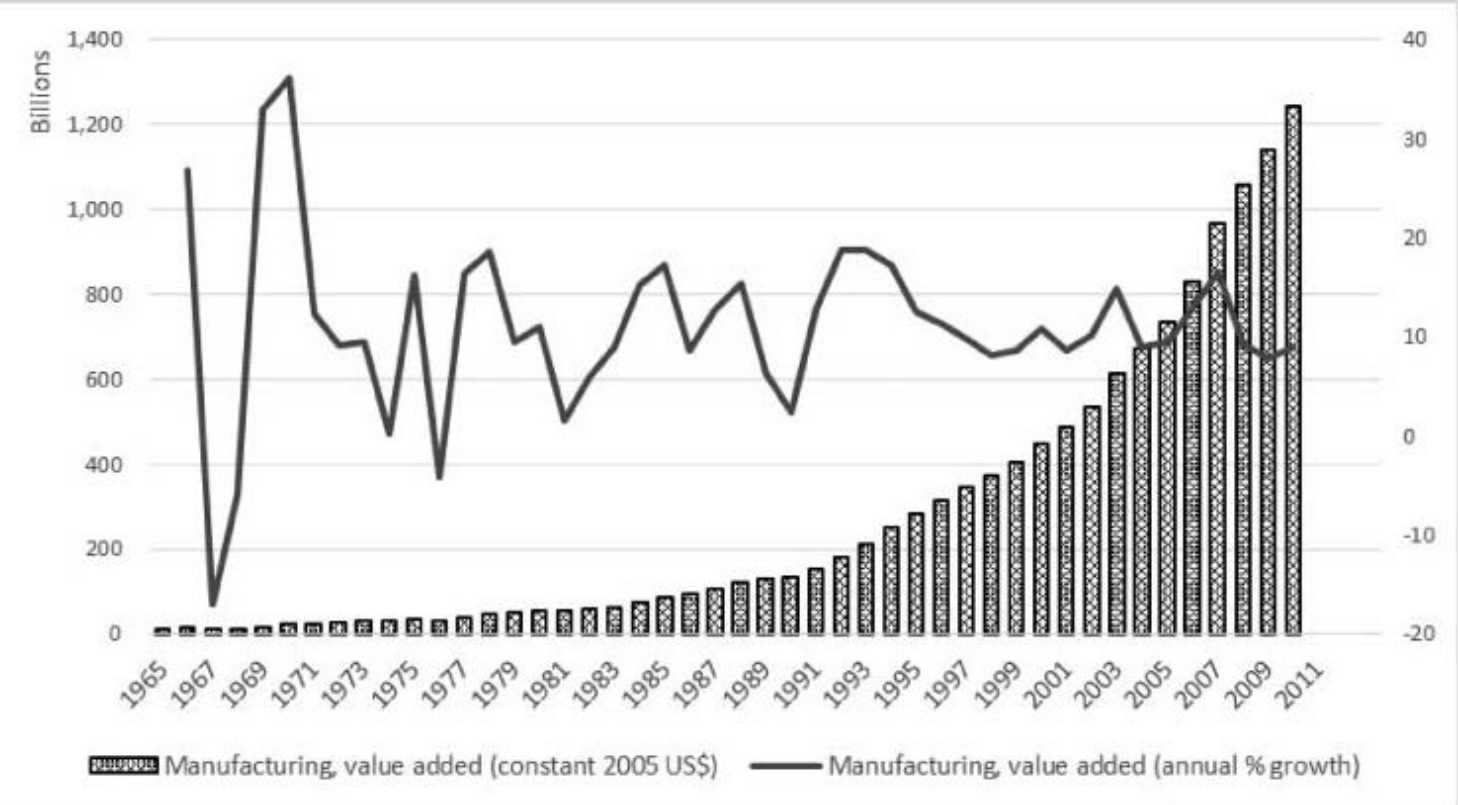

Figure 11. Manufacturing value added, China, 1965-2011.

Source: World Bank Institute (2012).

\section{Labour markets}

We discuss in this section the impact of internationalization and industrialization on China's labour market. In doing so, we analyse first the labour supply demand patterns followed by an evaluation of the uneven rural-urban flows, and wages and labour unions in China. The analysis is to assess if globalization and industrialization has resulted in an improvement in the material conditions of workers in China.

\subsection{Supply - demand analysis}

Labour supply and demand of China have increasingly been governed by a blend of policy directives and market forces after economic reforms. On the supply side, major changes in labour supply have taken place with the demographic restructuring, such as the one-child policy has lowered the dependency ratio. On the demand side, China's insertion into the global economy increased the demand for highquality labour as government policies focused on transforming economic specialization in the country from low to high value added activities. 


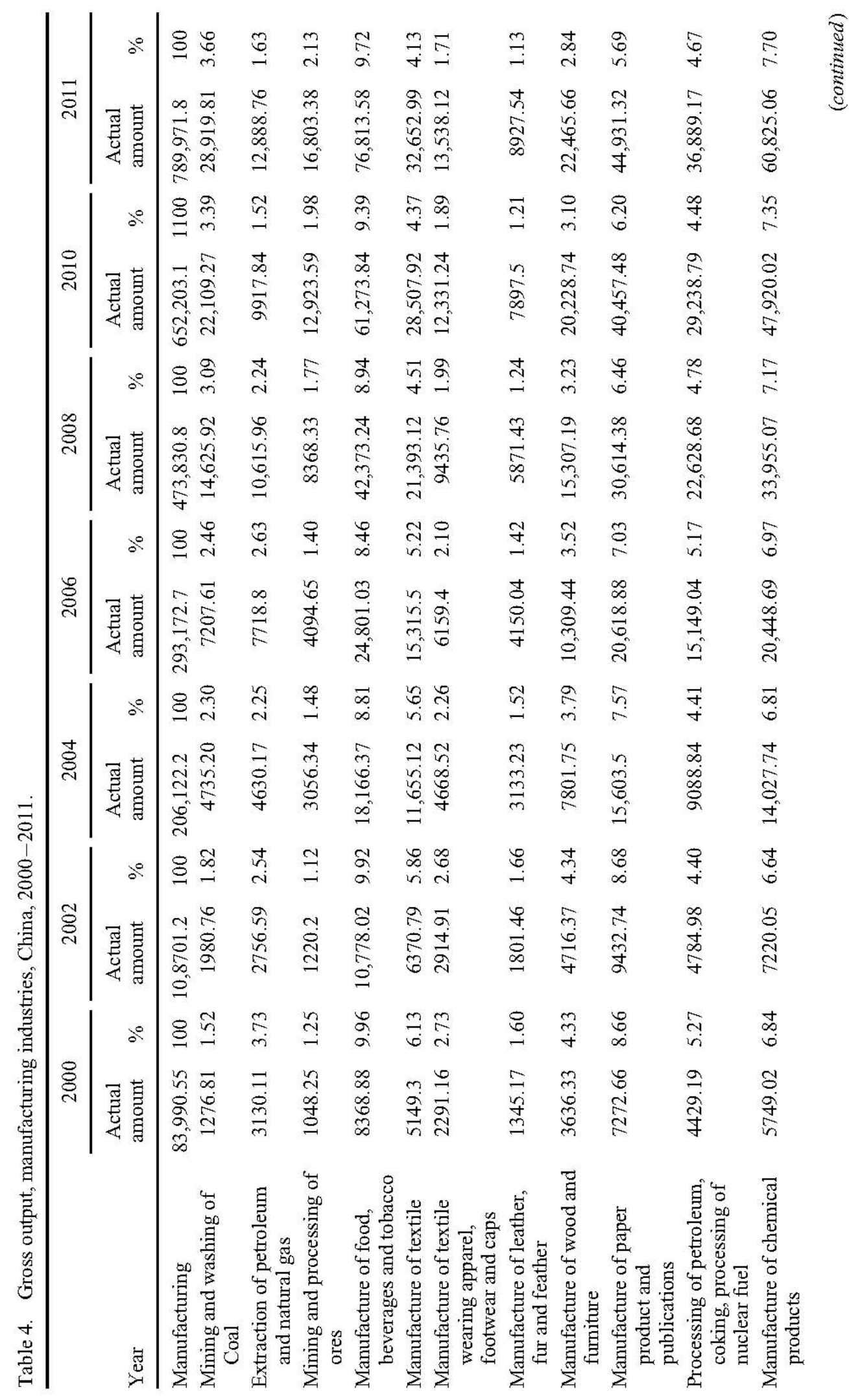




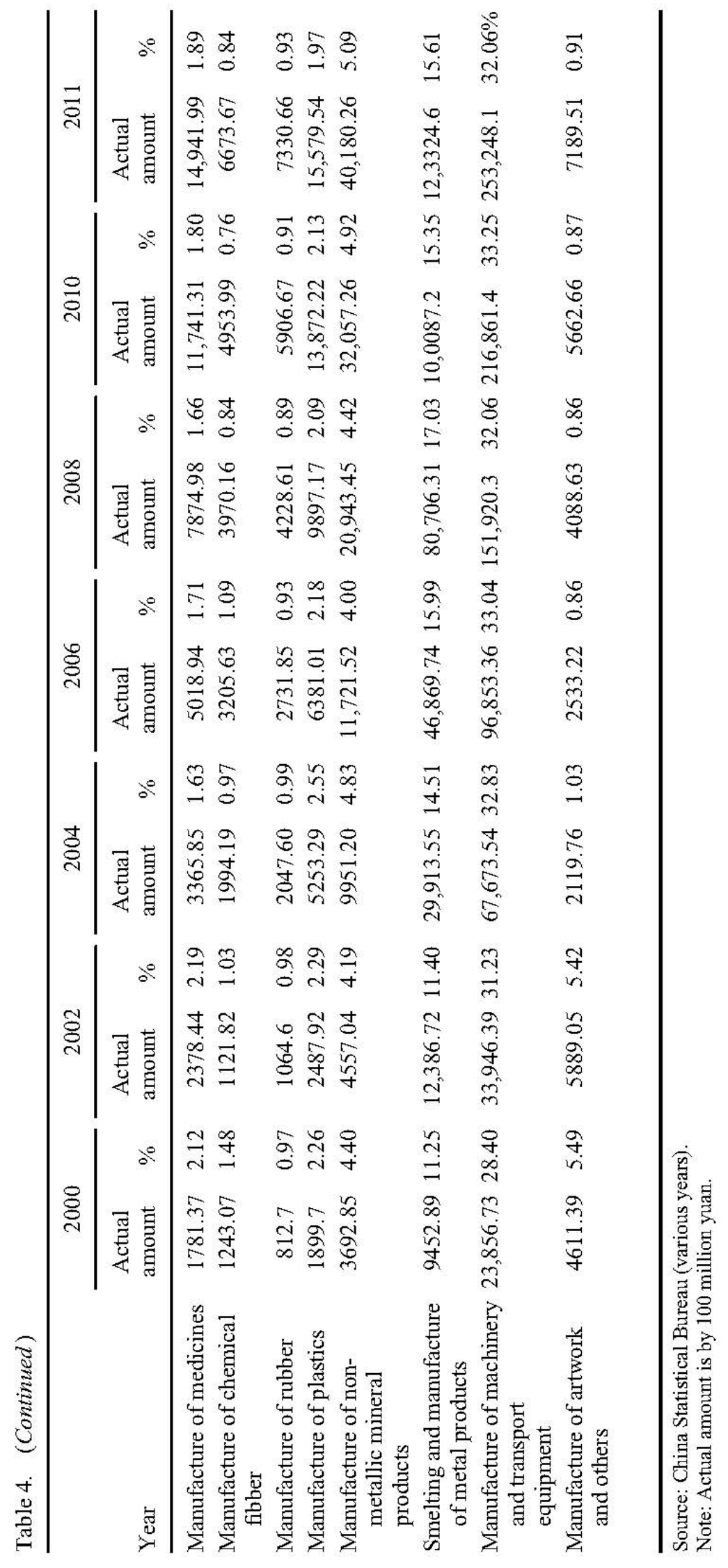




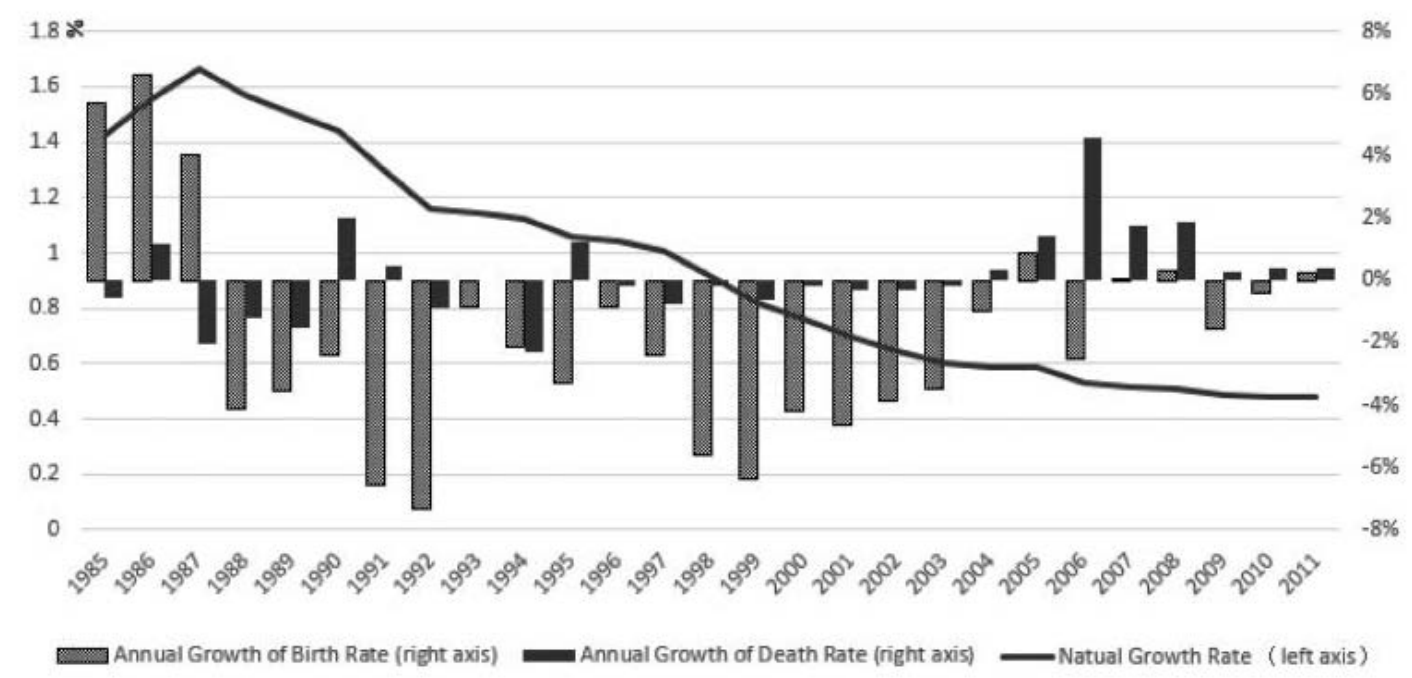

Figure 12. Bitth, death and population growth rates, China, 1978-2011.

Source: China Statistical Bureau (2012a).

\subsubsection{Labour supply}

Ostensibly, labour supply did not seem to be a problem for a large country like China with a population of over 1.3 billion in 2010. Industrialization drove large numbers of workers from agriculture to industry and services so that in the initial stages the massive supply of labour contributed to a low wage elasticity of economic growth ${ }^{v}$ in manufacturing in the 1990s. Rapid urbanization and industrialization helped raise the wage elasticity of growth as the industrial reserve disappeared. These changes were influenced by both export growth as well as demographic changes in China.

Demographic changes have contributed to a strong long-term shift in labour supply as the onechild policy sharply reduced population growth, which over the long run has eliminated the advantages of cheap labour. Labour-intensive industries have come under pressure as population growth slowed down sharply following a steep fall in birth rates from 1987 (Figure 12). Falling birth rates alongside a relatively stable death rate led to decline in population growth, which fell dramatically from $1.6 \%$ in 1982 to $0.5 \%$ in 2011.

The impact of demographic changes has not only affected the quantity but also in the age structure of labour supply. The disaggregation of population composition shows that although the population aged between 15 and 64 increased from 0.7 billion in 1978 to 1.0 billion in 2011, the population aged 0_14 dropped from 0.3 billion in 1978 to 0.2 billion in 2011, which shows that China will be facing a problem of a small young population in the long run. Hence, while the rapid expansion in 
human capital has improved job opportunities (demand), the one-child family policy has been a major cause of sharply contracting labour supply market in China.

\subsubsection{Labour demand}

Table 5. Annual industrial employment elasticity, China, 1998-2010.

\begin{tabular}{ccccccc}
\hline & & & & & & \\
Year & $\begin{array}{l}\text { Nominal gross } \\
\text { industrial output }^{\mathrm{a}}\end{array}$ & $\begin{array}{l}\text { Constant } \\
2000 \text { price }^{\mathrm{b}}\end{array}$ & $\begin{array}{l}\text { Output } \\
\text { growth }\end{array}$ & Employment $^{\mathrm{c}}$ & $\begin{array}{l}\text { Employment } \\
\text { growth }\end{array}$ & $\begin{array}{l}\text { employment } \\
\text { elasticity }\end{array}$ \\
\hline 1998 & $67,737.14$ & $68,266.55$ & N/A & 6195.81 & N/A & N/A \\
1999 & $72,707.04$ & $74,206.42$ & $8.70 \%$ & 5805.05 & $-6.31 \%$ & $(0.72)$ \\
2000 & $85,673.66$ & $85,673.66$ & $15.45 \%$ & 5559.36 & $-4.23 \%$ & $(0.27)$ \\
2001 & $95,448.98$ & $93,528.94$ & $9.17 \%$ & 5441.43 & $-2.12 \%$ & $(0.23)$ \\
2002 & $110,776.48$ & $107,917.66$ & $15.38 \%$ & 5520.66 & $1.46 \%$ & 0.09 \\
2003 & $142,271.22$ & $135,072.14$ & $25.16 \%$ & 5748.57 & $4.13 \%$ & 0.16 \\
2004 & $201,722.19$ & $179,131.78$ & $32.62 \%$ & 6622.09 & $15.20 \%$ & 0.47 \\
2005 & $251,619.50$ & $214,992.53$ & $20.02 \%$ & 6895.96 & $4.14 \%$ & 0.21 \\
2006 & $316,588.96$ & $260,638.13$ & $21.23 \%$ & 7358.43 & $6.71 \%$ & 0.32 \\
2007 & $405,177.13$ & $310,003.71$ & $18.94 \%$ & 7875.20 & $7.02 \%$ & 0.37 \\
2008 & $507,284.89$ & $360,050.81$ & $16.14 \%$ & 8837.63 & $12.22 \%$ & 0.76 \\
2009 & $548,311.42$ & $391,492.71$ & $8.73 \%$ & 8831.22 & $-0.07 \%$ & $(0.01)$ \\
2010 & $698,590.54$ & $467,902.81$ & $19.52 \%$ & 9544.71 & $8.08 \%$ & 0.41 \\
\hline
\end{tabular}

Notes: ${ }^{a}$ Nominal Gross Industrial Output figures converted to constant 2000 prices using the GDP deflator of China from World Bank Institute (2011).

${ }^{\mathbf{b}}$ In 10,000 yuan.

${ }^{\mathrm{c}}$ In 10,000 .

${ }^{\mathrm{d}}$ Industrial Employment Elasticity is calculated by dividing growth rate of employment over growth rate of real gross output.

Source: Calculated by authors based on China Statistical Bureau (2012a) \& World Bank (2011).

Whereas labour supply in China is determined by endogenous demographic factors, labour demand is sensitive to exogenous forces, such as globalization and industrialization. The transition of China from an agrarian to an industrial society has been driven by reforms since 1978, which has been the primary engine of global integration and economic structural change in the country. Since the focus here is on manufacturing, we estimate employment elasticity figures over the period where data is available, i.e. 1998_2010. vi Employment elasticity refers to the growth in employment for every unit output generated.

Annual industrial employment elasticities over the period 1998_2012, which is estimated by dividing industrial employment growth by industrial output growth, is shown in Table 5. Real output grew every year over the period 1998_2012, while employment fell over the years 1999_2001 and 2009. Large scale retrenchments by state owned enterprises (SOEs) saw employment facing negative growth rates in 1999_2001, which resulted in negative employment elasticities. The massive layoffs that followed painful reforms targeted at SOEs in the late 1990s were absorbed by the emerging non-state 
sector. ${ }^{\text {vii }}$ Except for 2009 (affected by the global financial crisis), positive industrial employment elasticities were recorded over the period 1999-2012.

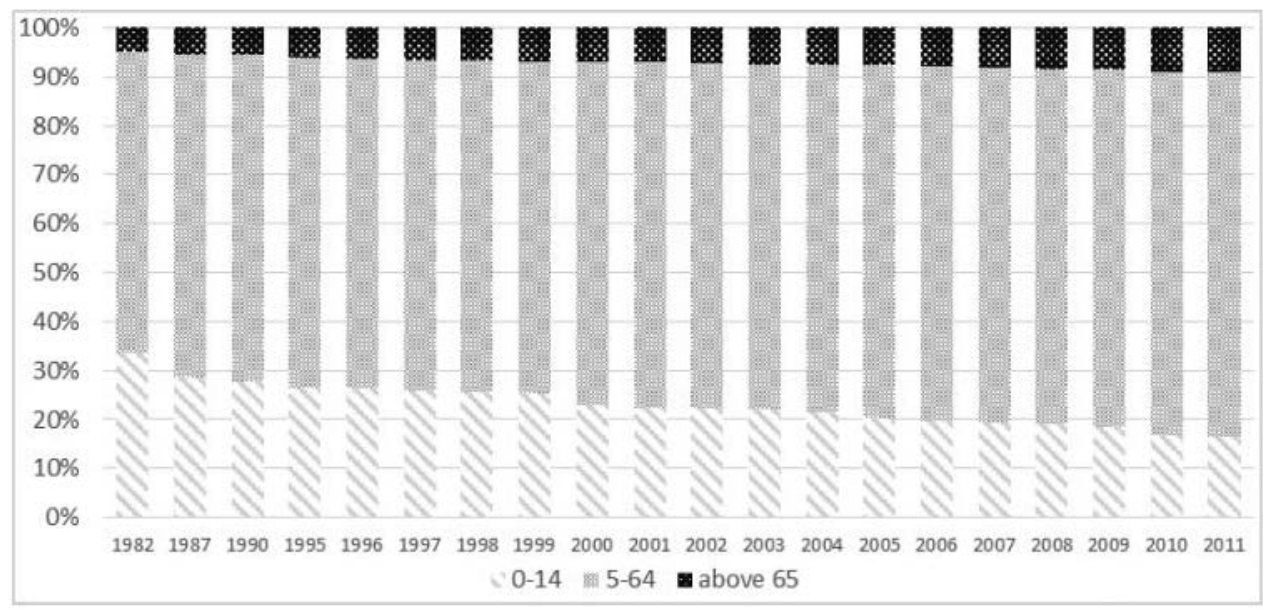

Figure 13. Population composition by age, China, 1982-2011.

Source: China Statistical Bureau (2012a).

The employment rate, the equilibrium point between labour supply and demand, jumped three times from 207 million to 761 million over the period 1952_2010 (Figure 13). Gripped by low wages and disguised unemployment during the communist rule, the social-market experiment following reforms boosted employment growth, which grew 553 million in 1989 to 647 million in 1990, recording its highest annual average growth rate of $17 \%$ in that period (Figure 14). The steady increase in labour force participation rate is a reflection of the nature of social market reforms China introduced to integrate with the global economy.

As a consequence of rapid labour absorption, the unemployment rate $\mathrm{viii}^{\mathrm{iii}}$ fell from $4.9 \%$ in 1980 to its trough of $1.8 \%$ in 1985 before a two-decade-long rise to $4.3 \%$ in 2003 (Figure 15). Reforms instituted on SOEs led to a rise in unemployment to $3.1 \%$ in 1989. Despite labour absorption, unemployment rose steadily until 2003 owing to structural unemployment caused partly by reforms faced by the SOEs. It has since either fallen or kept steady in trend terms, reaching $4.1 \%$ in 2011.

Rapid industrialization transformed the sectoral labour force participation rates as the share of employment in agricultural sector fell from $83.5 \%$ in 1952 to $34.8 \%$ in 2011, while the commensurate shares in the industrial sector rose from 7.4\% in 1952 to 29.5\% in 2011 (Figure 16). Employment by services grew from a share of $9.1 \%$ in 1952 to $35.7 \%$ in 2011. Economic reforms and the integration into the global economy transformed China from an agricultural to an industrial economy. Labour migration into the booming industrial and service sectors was the major reason, the introduction of largescale agricultural production using high technology was also important. 


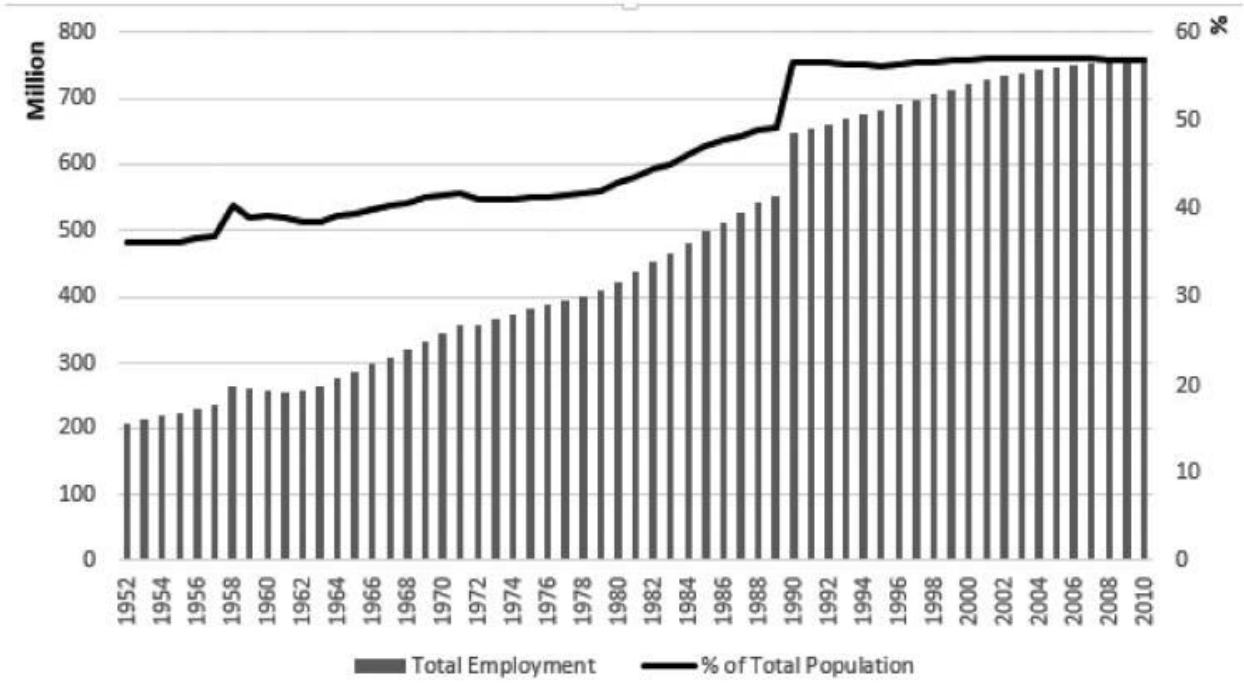

Figure 14. Employment, China, 1952-2010.

Source: China Statístical Bureau (various years).

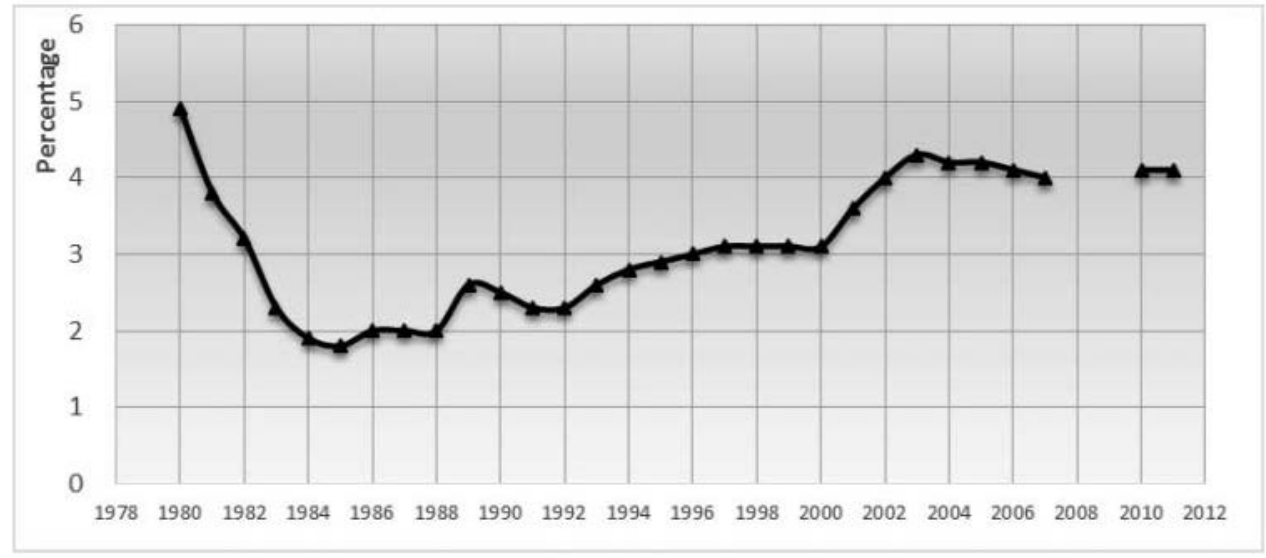

Figure 15. Unemployment rate, China, 1980-2011.

Source: World Bank Institute (2013).

Note: Data for 2008 and 2009 not available.

Manufacturing employment grew rapidly over the first reform period of 1978_1988 (Figure 17). A declining share of manufacturing in total employment from $15.9 \%$ in 1988 to $13.3 \%$ in 1990 is due to the fact that other sectors grew faster than manufacturing. Both employment, and the employment share of manufacturing in total employment grew in 1990_1996 as China enjoyed rapid growth similar to East Asia. Manufacturing employment fell again in 1997_2001 as a consequence of the Asian financial 
crisis of 1997_1998, and the relocation of labour-intensive manufacturing to Vietnam, Laos and Cambodia.

\subsection{Uneven distribution of labour}

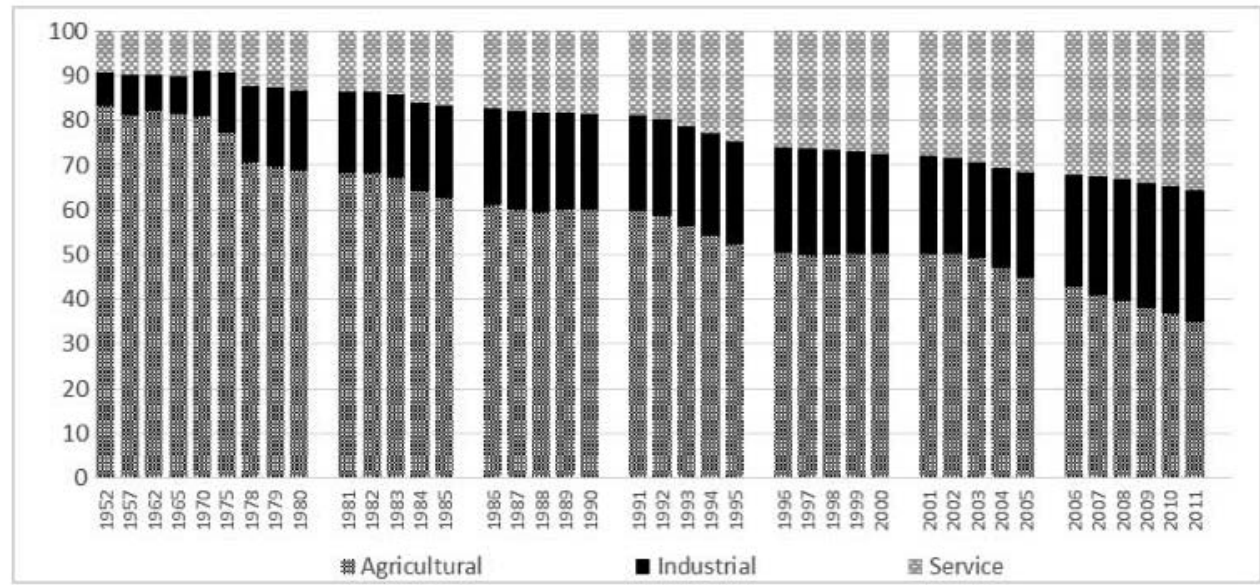

Figure 16. Employment breakdown by sectors, China, 1952-2011.

Source: China Statistical Bureau (2012b).

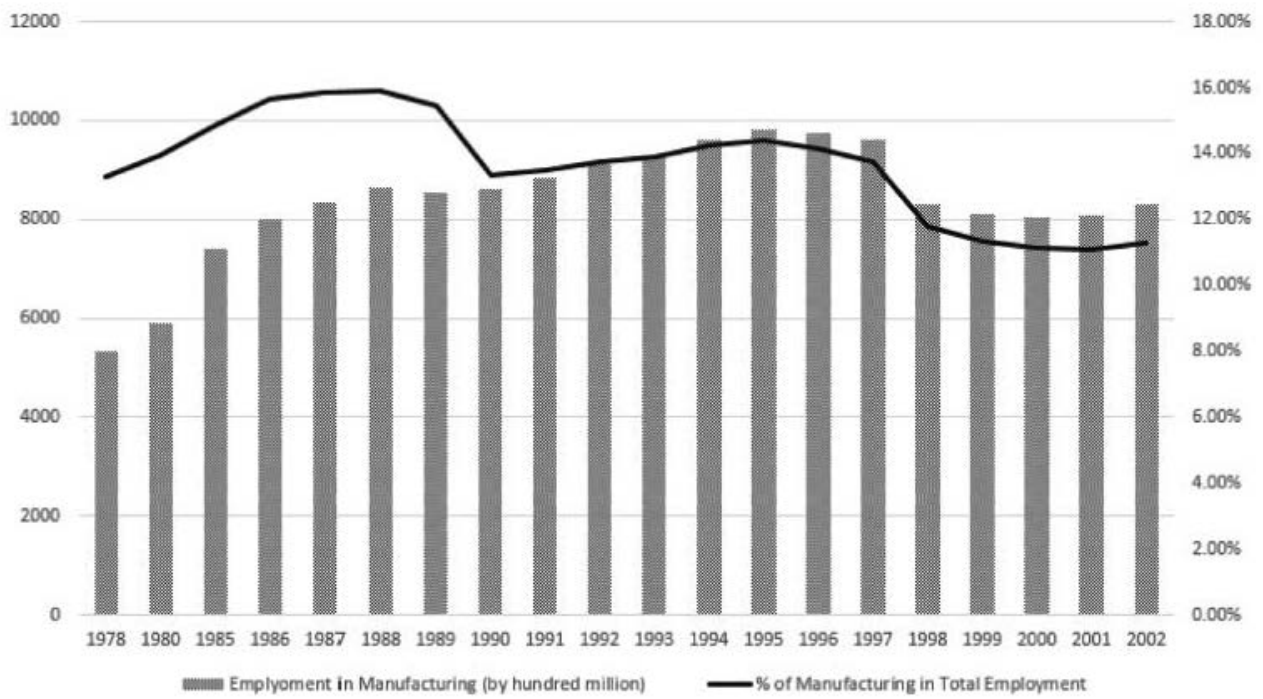

Figure 17. Employment in manufacturing, China, 1978-2008.

Source: China Statistical Bureau (various years).

Globalization and industrialization have also reproduced uneven regional distribution of labour in China.

The huge size of China, and its diverse geographical and socio-economic background has given the labour market multifarious development patterns. Global integration benefited the coastal provinces more than the inland provinces owing to both a greater focus on the former than the latter in the initial 
reform period, as well as, the proximity offered by the seafront. Hence, the Eastern coastal provinces have enjoyed structural change towards medium and high technology industries and higher wages than the inland provinces. In the meanwhile, household registration system (hukou), as a population control scheme, separated labour supply and demand geographically, so that labour supply from rural and Western inland regions is institutionally constrained to fill up strong labour demand generated by the urban and East coastal regions.

Until around 2000, government policy to promote trade and FDI favoured the East coastal areas. After 2000, the significant improvement of trade conditions offered by accession to the WTO resulted in the government extending trade and investment focus to the whole of China. However, the importance of access to trade routes prevented the movement of labour-intensive industries to the Western inland provinces. Hence, the growth of export-driven industries drove massive movement of labor from the Western inland provinces to the coastal Eastern provinces, aggravating regional inequality in employment and wages. Compared to the middle and western provinces, the Eastern coastal provinces account for around half of national employment in the period 2003_2011 (Figure 18). In 2010, 50.3\% of national employment was created by 11 out of 33 provinces/municipals in the Eastern China. The concentration in manufacturing was even higher at around $60 \%$ of national employment.

\subsection{Wages}

From a country that seemed like a base for unlimited cheap labour supply, China has transformed to experience rising real wages following a sustained rise in demand for labour and skills. Industrial exports aided strongly by important contributions from foreign capital, and foreign technology in particular has generated the demand for labour to record significant improvements in wages. The jump in real wage growth started in around 1998 when it was clear that the Multi-Fibre Arrangement _ which gave preferential market access in the developed countries to particular developing economies _ will be terminated by 2004 (Rasiah 2012). Although real wage growth fell below 7\% in 2004, both overall and manufacturing enjoyed a massive annual growth in real wages between $7 \%$ and $20 \%$ over the remaining 1998_2012 period (Table 6). Growth in manufacturing wages exceeded growth in overall wages in 1995, 1998_2000 and 2003. The higher growth in non-manufacturing real wages since 2005 is largely a case of catching up with manufacturing. 


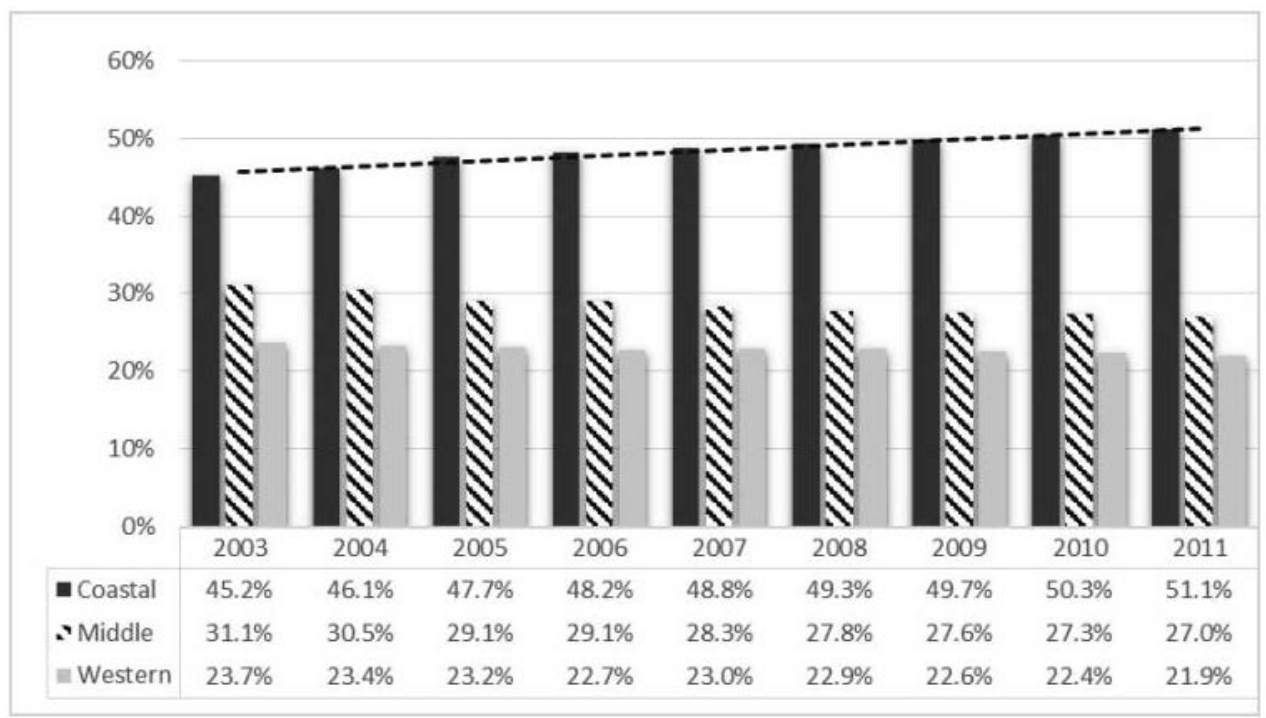

Figure 18. Share of employment by regions, China, 2003-2011.

Source: National Statistical Bureau (various years).

Table 6. Wages, overall and manufacturing, China, 1994-2009.

\begin{tabular}{rrrrrrrrr}
\hline & \multicolumn{4}{c}{ Overall } & & \multicolumn{4}{c}{ Manufacturing } \\
\cline { 2 - 3 } Year & Nominal & Constant 2000 prices & Growth rate & Nominal & Constant 2000 prices & Growth rate \\
\hline 1995 & 5348 & 5773.44 & $4.51 \%$ & 5199 & 5612.59 & $6.60 \%$ \\
1997 & 6444 & 6438.60 & $6.15 \%$ & 5979 & 5973.99 & $3.82 \%$ \\
1999 & 8319 & 8490.55 & $13.14 \%$ & 7874 & 8036.37 & $12.03 \%$ \\
2001 & 10,834 & $10,616.06$ & $13.75 \%$ & 9891 & & 9692.03 & $9.69 \%$ \\
2003 & 13,969 & $13,262.15$ & $10.03 \%$ & & 12,671 & & $12,029.83$ & $10.73 \%$ \\
2005 & 18,200 & $15,550.71$ & $10.00 \%$ & 15,934 & & $13,614.56$ & $7.58 \%$ \\
2007 & 24,721 & $18,914.20$ & $10.16 \%$ & 21,144 & & $16,177.41$ & $7.82 \%$ \\
2009 & 32,244 & $23,022.11$ & $12.24 \%$ & 26,810 & & $19,142.25$ & $10.51 \%$ \\
\hline
\end{tabular}

Source: China Statistical Bureau (2010b).

Clearly, the rapid growth in real wages in the world's most populous country demonstrates that the infusion of market forces in a protracted manner with the state retaining control to ensure that the interests of the poor are shielded is arguably a great example for other economies to study. The high increase in real wages obviously also suggests that China has managed to experience the high road to industrialization as defined by Piore and Sabel (1984), and Pyke and Sengenberger (1992). Rapid economic growth led by manufacturing has been accompanied by tangible improvements in the material conditions of labour as wages have grown significantly over the years.

As shown in Table 7, all manufacturing industries recorded rapid average annual real wage growth over the period 2001_2011. Overall (8.5\%) wages grew faster than manufacturing (8.1\%) wages for the reasons explained earlier. Tobacco and special purpose machinery recorded the highest wage 
growth in the manufacturing sector at $10.2 \%$ per annum. Between these two industries, tobacco by far enjoyed a massive real wage growth as mean wages 2000 prices in the industry reached 57,749 yuan compared to only 25,740 yuan in special purpose machinery. In addition, the manufacturing industries of textile, timber, bamboo and straw, furniture, paper and paper products, chemicals, nonmetallic mineral products, and general purpose machinery also enjoyed higher real wage growth than overall wage growth in China over the period 2001_2011.

In addition to rising wages caused by a greater rise in labour demand over labour supply and the rising premium for skilled and knowledge-based labour, the Chinese government has also reviewed its minimum wages every two years to ensure that the formal labour market is properly regulated. Minimum wages in China vary according to the regional and provincial differences in socio-economic conditions, as well as the concentration of labour across China. Although the national regulations, Regulations on Minimum Wage, was enforced in 2004 as a guideline to protect employees being fairly remunerated, the provincialization and decentralization processes following reforms allow local governments the regulatory space to initiate their own regulations based on specific socio-economic conditions. Moreover, the changing external economic environment caused by factors, such as, inflation, ${ }^{\text {ix }}$ have often required the authorities to calibrate minimum wages to reflect market conditions so as to protect the welfare of employees. Following the law to encourage provincial authority to adjust the minimum wage once every two years until it is lifted up to $40 \%$ of average wage of urban employees in 2015, the national average annual growth rate of minimum wage was increased by $22 \%$ in 2011 and $20.5 \%$ in 2010 . Among the provinces, Shanghai enjoyed the highest monthly and hourly minimum wages of 1620 yuan and 14 yuan, respectively, while the landlocked provinces/regions such as Guizhou and Chongqing recorded lower monthly and hourly minimum wages (Table 8). The dynamic economic provinces of Guangdong, Shenzhen, Jiangsu and Zhejiang also enjoyed relatively high minimum wages.

\subsection{Female labour}

We examine the gender issue in China's labour market here because female labour is attracting strong attention as they emerge from a background of subordination to males. Because China's early history has been dominated by men, the gender inequality that persisted since the Han Dynasty had remained until the establishment of People's Republic in 1949 when the Communist Party announced that the liberalization of women as a sign of modernization. Encouraged by Mao Zedong's motto of 'woman can also hold up half sky,' women were given equal rights to participate in the social relations of production. 


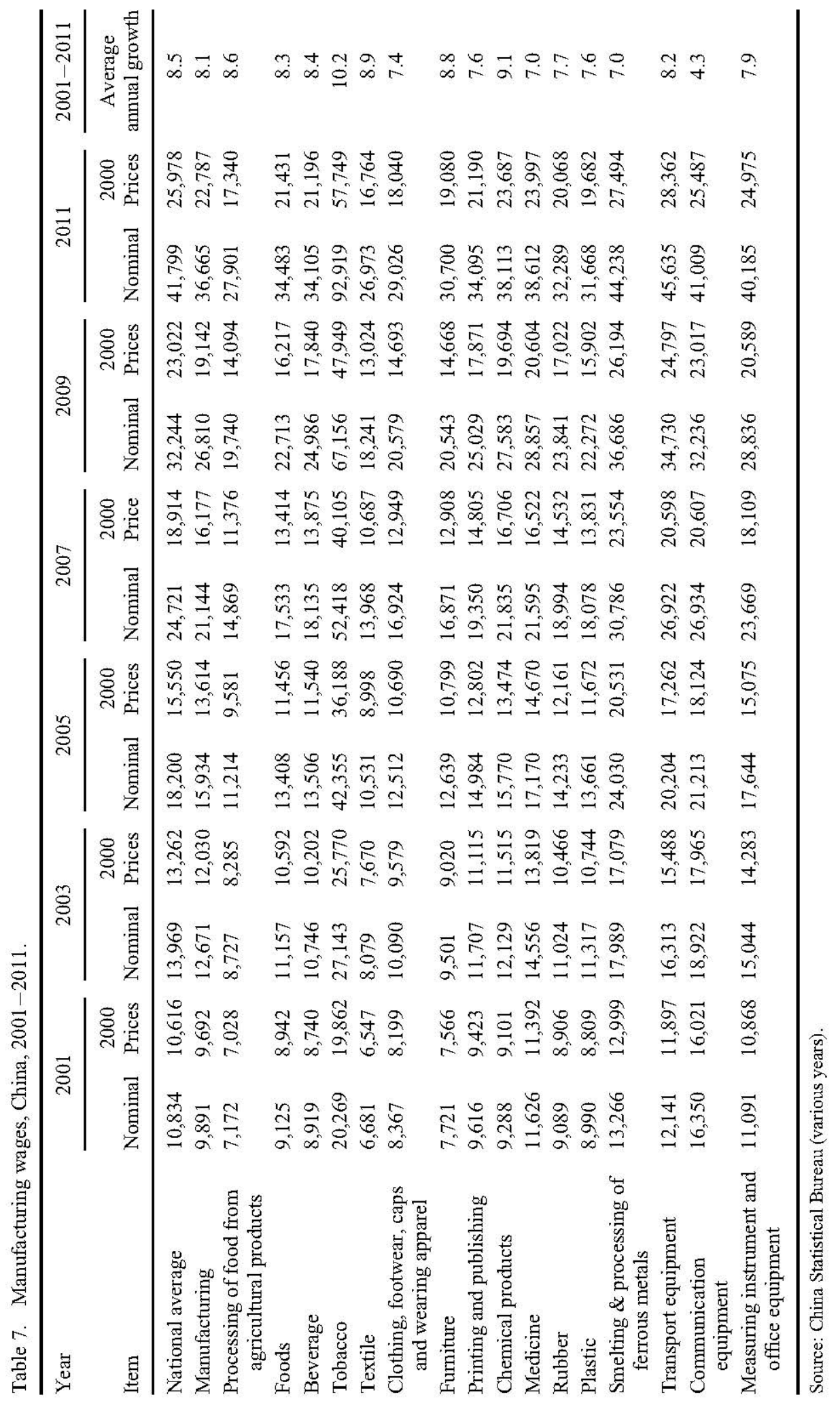


Table 8. Minimum wages by province, China, 2013.

\begin{tabular}{|c|c|c|c|c|c|c|c|c|}
\hline & \multicolumn{2}{|c|}{ January } & \multicolumn{2}{|c|}{ May } & \multicolumn{2}{|c|}{ June } & \multicolumn{2}{|c|}{ July } \\
\hline & Monthly & Hourly & Monthly & Hourly & Monthly & Hourly & Monthly & Hourly \\
\hline Shenzhen & 1500 & 13.3 & 1600 & 14.5 & 1600 & 14.5 & 1600 & 14.5 \\
\hline Zhejiang & 1470 & 12 & 1470 & 12 & 1470 & 12 & 1470 & 12 \\
\hline Shanghai & 1450 & 12.5 & 1620 & 14 & 1620 & 14 & 1620 & 14 \\
\hline Beijing & 1400 & 15.2 & 1400 & 15.2 & 1400 & 15.2 & 1400 & 15.2 \\
\hline Xinjiang & 1340 & 13.4 & 1340 & 13.4 & 1520 & 15.2 & 1520 & 15.2 \\
\hline Jiangsu & 1320 & 11.5 & 1320 & 11.5 & 1320 & 11.5 & 1480 & 13 \\
\hline Hebei & 1320 & 13 & 1320 & 13 & 1320 & 13 & 1320 & 13 \\
\hline Tianjin & 1310 & 13.1 & 1500 & 15 & 1500 & 15 & 1500 & 15 \\
\hline Guangdong & 1300 & 12.5 & 1550 & 15 & 1550 & 15 & 1550 & 15 \\
\hline Shandong & 1240 & 13 & 1380 & 14.5 & 1380 & 14.5 & 1380 & 14.5 \\
\hline Fujian & 1200 & 12.7 & 1200 & 12.7 & 1200 & 12.7 & 1200 & 12.7 \\
\hline Inner Mongolia & 1200 & 10.2 & 1200 & 10.2 & 1200 & 10.2 & 1200 & 10.2 \\
\hline Hunan & 1160 & 11.5 & 1160 & 11.5 & 1160 & 11.5 & 1160 & 11.5 \\
\hline Heilongjiang & 1160 & 11 & 1160 & 11 & 1160 & 11 & 1160 & 11 \\
\hline Shaanxi & 1150 & 11.5 & 1150 & 11.5 & 1150 & 11.5 & 1150 & 11.5 \\
\hline Tibet & 1150 & 10.5 & 1150 & 10.5 & 1150 & 10.5 & 1150 & 10.5 \\
\hline Jilin & 1150 & 10 & 1150 & 10 & 1150 & 10 & 1150 & 10 \\
\hline Shanxi & 1125 & 12.3 & 1290 & 14 & 1290 & 14 & 1290 & 14 \\
\hline Hubei & 1100 & 10 & 1100 & 10 & 1100 & 10 & 1100 & 10 \\
\hline Liaoning & 1100 & 11 & 1100 & 11 & 1100 & 11 & 1300 & 12.5 \\
\hline Ningxia & 1100 & 11 & 1300 & 12.5 & 1300 & 12.5 & 1300 & 12.5 \\
\hline Yunnan & 1100 & 10 & 1265 & 11 & 1265 & 11 & 1265 & 11 \\
\hline Henan & 1240 & 11.7 & 1240 & 11.7 & 1240 & 11.7 & 1240 & 11.7 \\
\hline Qinghai & 1070 & 10.8 & 1070 & 10.8 & 1070 & 10.8 & 1070 & 10.8 \\
\hline Sichuan & 1050 & 11 & 1050 & 11 & 1050 & 11 & 1200 & 12.7 \\
\hline Chongqing & 1050 & 10.5 & 1050 & 10.5 & 1050 & 10.5 & 1050 & 10.5 \\
\hline Hainan & 1050 & 9.2 & 1050 & 9.2 & 1050 & 9.2 & 1050 & 9.2 \\
\hline Anhui & 1010 & 10.6 & 1010 & 10.6 & 1010 & 10.6 & 1010 & 10.6 \\
\hline Guangxi & 1000 & 8.5 & 1200 & 10.5 & 1200 & 10.5 & 1200 & 10.5 \\
\hline Gansu & 980 & 10.3 & 1200 & 12.7 & 1200 & 12.7 & 1200 & 12.7 \\
\hline Guizhou & 1030 & 11 & 1030 & 11 & 1030 & 11 & 1030 & 11 \\
\hline Jiangxi & 870 & 8.7 & 1230 & 12.3 & 1230 & 12.3 & 1230 & 12.3 \\
\hline
\end{tabular}

Source: Bureau of Human Resource and Social Security, various provinces, (2013).

Women's participation in the formal labour market became more pronounced since market reforms were introduced in 1978. Attracted by the better urban incomes, young migrant women left their homes from rural areas to seek employment in industrial areas to supplement household incomes or to support their male siblings to attend college. Statistics from Shenzhen General Labour Union (2003) show that $70 \%$ of the 5.5 million migrant workers were females in the Shenzhen Special Economic Zone in 2003. In one of its sub-districts, i.e. Nanshan, female labour accounted for $80 \%$ of the entire workforce with an average age of 23. However, lacking the skills and knowledge of urban educated woman, most rural female migrants are employed in segmented labour markets in the 
informal and low-wage employment sectors. Young migrant workers, with minimal education and awareness of labour-related rights found are largely exposed to low-wage employment with weak labour protection and physical and psychological problems.

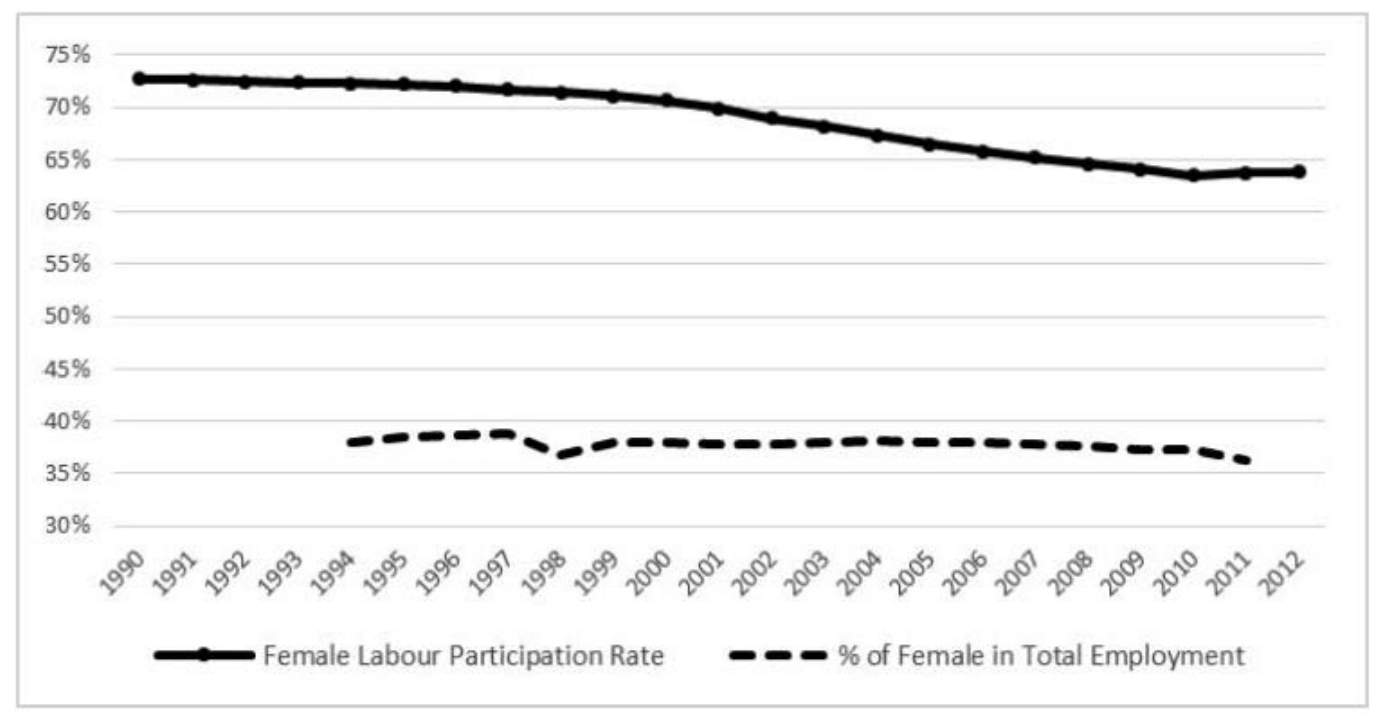

Figure 19. Female labour participation rate, China, 1990-2012 (\%).

Source: World Bank (2012).

The development of female employment since the Communist Party took over is associated with the following: first, the modernization of household relations as women began to enter education stream in large numbers, (including in technical fields), and second, market reforms since 1978 provided massive demand for female labour. However, while these two developments unleashed strong motivation for women to work, the gradual withdrawal of the state from economic activities triggered a gradual fall in female labour force participation rates, which dropped from $72.7 \%$ in 1990 to $63.8 \%$ in 2012 (Figure 19). The steep decline happened since 1998 until middle 2000s, which is believed to be a consequence of large-scale SOE reforms as a massive number of employees were retrenched. Rising incomes also led a number of females to stay home and take care of household chores. Hence, females in the labour force stabilized at 36\%_38\% in the period 1994_2011.

Overall and female employment in manufacturing has started to decline since 1994 before both of them experienced a rise after bottoming in 2003. The female composition declined from its highest of $45 \%$ in 1995 to its lowest of 39\% in 2011(Figure 20). The declining trend in the female share of employment in manufacturing is a consequence of industrial upgrading from low technology labourintensive industries, such as, clothing and tools manufacturing, to middle technology industries, such as, machinery manufacturing. While the former is dominated by female workers, the latter is dominated by 
male workers. Nevertheless, manufacturing alone accounted for $30.9 \% \_42.4 \%$ of overall female employment over the period 1994_2011 (Figure 21).

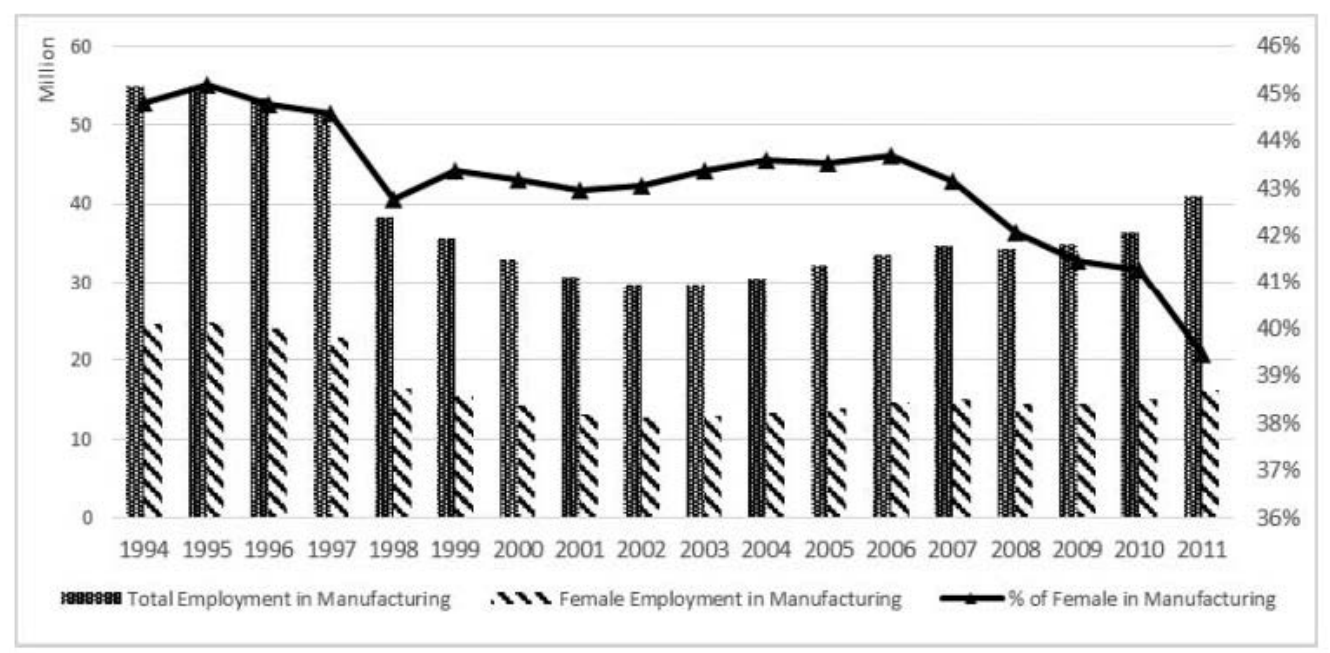

Figure 20. Manufacturing employment, China, 1994-2011.

Source: China Statistical Bureau (various years).

Although China has enjoyed a relatively high female labour participation rate compared to most developing economic and the smallest rural-urban and gender wage gaps among developing countries (World Bank Institute 2012), female labour in manufacturing shows longer working hours than workers (including female) in the overall economy over the period 2001_2011. This gap has narrowed since over the period 2007_2011. In general, both male and female working hours in manufacturing is much longer compared to other sectors (Table 9). However, there is no discernible difference in male-female working hours over the period 2001_2011 to suggest that women work longer than men in manufacturing. The narrowing gap in working hours between manufacturing and other sectors also shows a shift in economic activity away from manufacturing to the other sectors, such as, services.

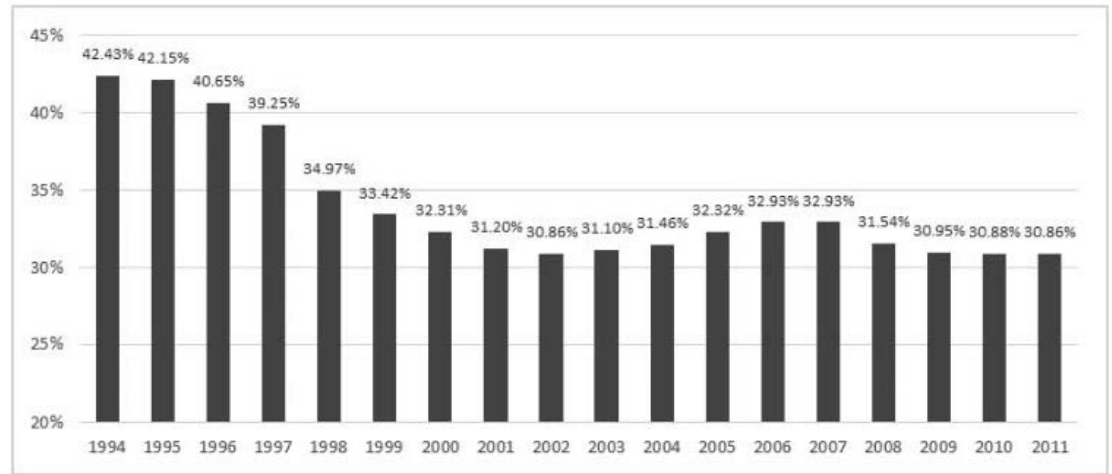

Figure 21. Female manufacturing employment in total employment, China, 1994-2011. Source: China Statistical Burean (various years). 
Table 9. Urban female average weekly working hours, China, 2001-2011.

\begin{tabular}{ccccccc}
\hline Year & National & $\begin{array}{c}\text { Male } \\
\text { National }\end{array}$ & $\begin{array}{c}\text { Female } \\
\text { National }\end{array}$ & Manufacturing & $\begin{array}{c}\text { Male in } \\
\text { manufacturing }\end{array}$ & $\begin{array}{c}\text { Female in } \\
\text { manufacturing }\end{array}$ \\
\hline 2001 & 44.9 & 45.2 & 44.5 & 44.7 & 44.8 & 44.7 \\
2002 & 45.2 & 45.6 & 44.7 & 46.0 & 45.6 & 46.5 \\
2003 & 45.4 & 45.8 & 44.9 & 46.4 & 46.2 & 46.6 \\
2004 & 45.5 & 46.0 & 44.9 & 46.9 & 46.5 & 47.5 \\
2005 & 47.8 & 48.7 & 46.1 & 51.1 & 51.0 & 51.3 \\
2006 & 47.3 & 48.3 & 45.9 & 50.4 & 50.3 & 50.5 \\
2007 & 45.5 & 46.8 & 44 & 49.4 & 49.6 & 49.2 \\
2008 & 44.6 & 45.7 & 43.1 & 47.9 & 48.0 & 47.7 \\
2009 & 44.7 & 45.9 & 43.2 & 48.5 & 48.6 & 48.4 \\
2010 & 47.0 & 47.7 & 46.1 & 49.0 & 49.0 & 49.0 \\
2011 & 46.2 & 47 & 45.2 & 48.1 & 48.2 & 47.9 \\
\hline
\end{tabular}

Source: China Statistical Bureau (various years).

However, severe challenges still face China's female workers. Although industrialization and globalization have improved wages, female workers earned less than $31 \%$ on average the wages of man in 2011 for doing the same job. Also, gender discrimination also affected female job seekers in the employment market with many employers preferring male employees owing to legal protection for maternity leave and other preferential treatment given to women. In addition, urban migrant female workers often face serious social problems. Given the special characteristic of unions in China, which are a subordinate organ of government, female labour often lacks empowerment to seek their labourrelated rights. The government's sanctioning of other forms of unionization denied the All-China Federation of Trade Unions the legitimacy to fight for worker's rights. As a consequence, the collective bargaining power of migrant women workers is largely absent to assist them to seek their rights from employers. Hence, unrests involving worker abuse have continued to explode in China, such as, the notorious Foxconn suicide scandal.

\section{Conclusions}

Although we have not examined the state of freedom and happiness the people of China may have enjoyed when the gates to global integration were opened in 1978 , the evidence shows that massive trade and investment flows have followed since reforms began, which has not only stimulated rapid economic growth and structural change but it has also generated significant improvement in real wages, especially from the 1990s. The advantages offered by the seafront and an earlier focus by the government made the Eastern coastal provinces the largest beneficiaries of globalization in China. 
Manufacturing value added and structural change and wages have grown the fastest in these states. Nevertheless, the middle inland provinces and federal territories of Jiangsu and Beijing have also benefited considerably from the transformation. Although regional inequalities have widened as a consequence of the faster development of the Eastern provinces compared to the Western provinces the evidence shows that material progress has been felt by most provinces.

The evidence shows that global integration through the infusion of capitalist organization under a socialist structure where the central government has increasingly decentralized planning to absorb provincial and municipal participation in decision making has been successful in ensuring long run growth, structural change and improvements in wages. The government's focus on targeting technological capability has been important in the structural transformation of manufacturing from lower to higher value added activities. Elsewhere Mathews (2014) has offered convincing evidence to show how China is driving Asia's new great transformation through a focus on renewable energy to power economic growth.

However, China's massive industrial labour market has also been gripped by social problems. Manufacturing workers on average still work longer than other workers in the economy. While female labour force participation rates are high compared to other developing countries, rising wages has also capped further increases since the 2000s as women have chosen to handle household chores more. However, not everything has been rosy as vulnerable industrial rural migrant workers have also been exposed to abuse by factories from time to time. Also, women on average still earn around one-third of men for similar work done in China.

\section{Acknowledgements}

We are grateful to comments from two referees. The usual disclaimer applies.

\section{References}

China Global Investment Tracker. 2011. American Enterprise Institute \& The Heritage Foundation.

Accessed October 21, 2014. http://www.heritage.org/research/projects/china-globalinvestmenttracker-interactive-map

China Statistical Bureau. 2010a. China Statistics Yearbook, edited by J.T. Ma. Beijing: State Statistical Bureau.

China Statistical Bureau. 2010b. China Labour Statistical Yearbook, edited by Z.B. Zhang. Beijing: 
Department of Population and Employment Statistics of the State Statistics Bureau \& Department of Planning and Finance of the Ministry of Human Resources and Social Security.

China Statistical Bureau. 2012a. China Statistics Yearbook, edited by J.T. Ma. Beijing: State Statistical Bureau.

China Statistical Bureau. 2012b. China Labour Statistical Yearbook, edited by Z.B. Zhang. Beijing:

Department of Population and Employment Statistics of the State Statistics Bureau \& Department of Planning and Finance of the Ministry of Human Resources and Social Security.

Kaldor, N. 1967. Strategic Factors in Economic Development. New York, NY: New York State School of Industrial and Labor Relations, Cornell University.

Mathew, J.A. 2014. Greening Capitalism: How Asia is Driving the New Great Transformation. Stanford: Stanford University Press.

Piore, M.J., and C.F. Sabel. 1984. The Second Industrial Divide: Possibilities for Prosperity. New York, NY: Basic Books.

Pyke, F., and W. Sengenberger. 1992. Industrial Districts and Local Economic Regeneration. Geneva: International Labour Organization (ILO).

Rasiah, R. 2012. "Beyond the Multi-Fibre Agreement: How are Workers in East Asia Faring?.” Institutions and Economies 4 (3): 1_20.

Rasiah, R., X.-X. Kong, and J. Vinanchiarachi. 2011. "Moving Up in the Global Value Chain in Button Manufacturing in China." Asia Pacific Business Review 17 (2): 161_174. doi: 10.1080/ 13602381.2011 .533508

Rasiah, R., Z. Miao, and K.X. Xin. 2013. “Can China's Miraculous Economic Growth Continue?” Journal of Contemporary Asia 43 (2): 295_313. doi:10.1080/00472336.2012.740940

Shenzhen General Labour Union. 2003. “The Cooperative of Female Migrant in Shenzhen. 2014." http://gd.news.sina.com.cn/local/2003-03-10/18107.html.

UNCTAD. 2011. World Investment Report. Geneva. http://unctad.org/en/PublicationsLibrary/ wir2012_embargoed_en.pdf

World Bank. 2011. World Development Indicators. http://data.worldbank.org/country/china\#cp_wdi World Bank. 2012. World Development Indicators. http://data.worldbank.org/country/china\#cp wdi World Bank Institute. 2011. World Development Indicators. Washington, DC: World Bank Institute.

World Bank Institute. 2012. World Development Indicators. Washington, DC: World Bank Institute.

World Bank Institute. 2013. World Development Indicators. Washington, DC: World Bank Institute.

World Development Indicators. 2012. The World Bank. http://data.worldbank.org/country/china\#cp_wdi World Trade Organization. 2012. International Trade Statistics. Geneva: World Trade Organization. 
Young, A. 2003. “Gold into Base Metals: Productivity Growth in the People's Republic of China

During the Reform Period." Journal of Political Economy 111: 1220_1261.

Zhang, M., and R. Rasiah. 2014. “Institutional Change and State Owned Enterprises in China's

Urban Housing Market." Habitat International 41 (Jan.): 58_68.

i In general, the collection and reporting of statistics raise a number of problems. Nevertheless, statistics from a large and rapidly growing economy like China will be superior to those backward countries.

ii Moroccan geographer Muhammad al-Idrisi had recorded the appearance of Chinese merchant ships in the Indian Ocean in 1154, and their voyages extended as far as Yemen.

iii Interviews with a senior German engineer of Shanghai Volkswagen on 29 September 2000 in Shanghai.

iv For an account of the role of the central, provincial and municipal governments in the growth of button manufacturing in Qiaotou.

$\checkmark$ The low price elasticity may also be explained by the absence of a well-established market mechanism.

vi The observation period extends from 1998 to 2010 in order to capture the industry development after reforms and insertion of global economy, especially the entrance of WTO in 2000. The period before 1998 was not taken into discussion, as the changes in elasticity was not significant enough to examine the impact of globalization and industrialization on labour market.

vii The aggregate number of laid-off workers was 27 million from 1998 to 2004. The number of layoffs reached its peak of 6.6 million in 2000.

viii It indicates the share of unemployment on total labour force.

ix 9 . According to the Law, the minimum wage is a function of a set of socio-economic factors, which is expressed as follows:

$$
M=f(C, S, A, U, E, a)
$$

where M: Level of Minimum Wage; C: Urban Average of Life Expenses; S: Social Security

Fund and Housing Provident Fund by Employees; A: Average Wage of Employees; U: Unemployment

Rate; E: Level of Economic Development; and a: adjustment factor. 